\title{
Ecological patterns of blood-feeding by kissing-bugs (Hemiptera: Reduviidae: Triatominae)
}

\author{
Jorge Eduardo Rabinovich ${ }^{1 /+}$, Uriel Dan Kitron ${ }^{2,3}$, Yamila Obed', \\ Miho Yoshioka ${ }^{2}$, Nicole Gottdenker ${ }^{4}$, Luis Fernando Chaves ${ }^{2,5,6}$
}

\begin{abstract}
${ }^{1}$ Centro de Estudios Parasitológicos y de Vectores, Universidad Nacional de La Plata, Calle 2 584, 1900 La Plata, Buenos Aires, Argentina ${ }^{2}$ Environmental Studies, Emory University, Atlanta, GA, USA ${ }^{3}$ Fogarty International Center, National Institutes of Health, Bethesda, MD, USA ${ }^{4}$ Department of Pathology, College of Veterinary Medicine, University of Georgia, Athens, GA, USA ${ }^{5}$ Programa de Investigación en Enfermedades Tropicales, Escuela de Medicina Veterinaria, Universidad Nacional, Heredia, Costa Rica ${ }^{6}$ Laboratorio de Biología Teórica, Instituto de Ecología y Zoología Tropical, Facultad de Ciencias, Universidad Central de Venezuela, Caracas, Venezuela
\end{abstract}

Host use by vectors is important in understanding the transmission of zoonotic diseases, which can affect humans, wildlife and domestic animals. Here, a synthesis of host exploitation patterns by kissing-bugs, vectors of Chagas disease, is presented. For this synthesis, an extensive literature review restricted to feeding sources analysed by precipitin tests was conducted. Modern tools from community ecology and multivariate statistics were used to determine patterns of segregation in host use. Rather than innate preferences for host species, host use by kissing-bugs is influenced by the habitats they colonise. One of the major limitations of studies on kissing-bug foraging has been the exclusive focus on the dominant vector species. We propose that expanding foraging studies to consider the community of vectors will substantially increase the understanding of Chagas disease transmission ecology. Our results indicate that host accessibility is a major factor that shapes the blood-foraging patterns of kissing-bugs. Therefore, from an applied perspective, measures that are directed at disrupting the contact between humans and kissing-bugs, such as housing improvement, are among the most desirable strategies for Chagas disease control.

Key words: foraging - null models - diet analysis - multivariate statistics - Chagas disease - niche breadth

The biology of kissing-bugs (Triatominae: Reduviidae), which are vectors of Chagas disease, has been relatively well studied. Although the amount of knowledge is scarce when compared with other vectors, such as ticks or mosquitoes, a valuable body of knowledge on the physiology, behaviour, genetics, life history, geographical distribution, habitat use and feeding patterns and preferences has been accumulated in the century following Dr Carlos Chagas' groundbreaking discovery of the role of kissing-bugs as vectors of Trypanosoma cruzi (Chagas 1909). For kissing-bugs, hematophagy is a source of energy and nutrients. Unlike other bloodsucking insect vectors such as mosquitoes and sandflies, whose larvae rely on resources other than blood, kissing-bugs are strictly hematophagous (in a wide sense, including feeding on invertebrate haemolymph) during their entire life cycle (Lehane 2005). Earlier studies on kissing-bugs described the importance and wide range of their diet (Brumpt 1927). The process of triatomine feeding has been studied from at least three different perspectives: (i) physiological and behavioural, (ii) fitness (effects on survival and reproduction) and (iii) patterns of host use in the field and in laboratory-based tools, including those applied to other vectors, such as mosquitoes and sandflies (Añez et al. 1994, Hamer et al.

+ Corresponding author: jorge.rabinovich@gmail.com

Received 23 January 2011

Accepted 6 May 2011
2009). The following is a summary of the research on kissing-bug haematophagy presented from these three perspectives as opposed to an exhaustive review.

The physiological approach to the study of kissingbugs - The physiological approach is likely the best developed and the following presents the variety of topics that are particularly well studied in kissing-bugs: extreme starvation and recovery (Wigglesworth 1982), action of digestive cells (Rocha et al. 2010), changes in haemolymph serotonin levels (Lange et al. 1989), intestinal erythrocyte agglutination (Araujo et al. 2009), nutritionally essential amino acids (Pickett \& Friend 1965), metabolic pathways for dietary lipids (Canavoso et al. 2004), salivary secretion during feeding (Friend \& Smith 1971, Ribeiro \& Garcia 1980, 1981, Barbosa et al. 1999, Faudry et al. 1999, Sant'Anna et al. 2001, Andersen et al. 2005, Soares et al. 2006), release of $\mathrm{CO}_{2}$ following feeding (Bradley et al. 2003), temperature-induced responses, $\mathrm{CO}_{2}$ and other compounds in host search (Smith \& Friend 1972, Taneja \& Guerin 1997, Canals et al. 1999, OtáloraLuna et al. 2004, Barrozo \& Lazzari 2006), the effect of gorging stimulation on different compounds (Friend 1965, Friend \& Smith 1971, 1982, Smith \& Friend 1976) and humoral factors transmitted to the brain (Mulye \& Davey 1995), the effects of diet composition on ecdysis (Azambuja et al. 1993), the influence of nutrition on immune responses (Feder et al. 1997), fat body reserves (Canavoso \& Rubiolo 1998) and haemolymph (Paz et al. 1988), pressures produced in the pharyngeal pump (Bennet-Clark 1963a), proteolytic enzymes in the midgut (Garcia \& Guimarães 1979), and the relationship between feeding and respiration (Cirano \& Zeledón 1964). 
Several aspects of feeding-related behaviour in triatomines have also been well studied. Such aspects include feeding preferences (Quintal \& Polanco 1977), avoidance of excessive warming during feeding (Lazzari et al. 2009), importance of nutritional status in flight initiation and dispersal (Lehane \& Schofield 1982, Lehane et al. 1992, Noireau \& Dujardin 2001, Emmanuelle-Machado et al. 2002, Ceballos et al. 2005), avoidance of predators during feeding (Bodin et al. 2009a, b), frequency and size of the blood intake (Maddrell 1963, Wood 1976, Montenegro \& Pasina 1984, Maifrino et al. 1986, Pietrokovsky et al. 1996, Pereira et al. 1998), control of meal size (Bennet-Clark 1963b) and the relationship between feeding and defecation patterns as well as other aspects of feeding with epidemiological importance (Wood 1951, Dias 1956, Zeledón et al. 1970, 1977, Da Rocha e Silva et al. 1979, Crocco \& Catalá 1996, Kollien \& Schaub 1998, Zabala \& D' Antonio 1988, Braga \& Lima 1999, Aldana et al. 2001, Emmanuelle-Machado et al. 2002, Nattero et al. 2002, Almeida et al. 2003, Arévalo et al. 2007, Rodriguez et al. 2008, Klotz et al. 2009).

Studies have been conducted on the relationship between the impacts of the triatomine feeding process and demographic parameters (Davies 1990, Malo et al. 1993, Emmanuelle-Machado et al. 2002), mortality and fecundity (Goodchild 1955, Hays 1965, Regis 1977, Patterson 1979, Catalá de Montenegro 1989, Braga et al. 1998, Braga \& Lima 2001, Davey 2007), development time (Martinez-Ibarra et al. 2003, Martinez-Ibarra \& Novelo-López 2004), resistance to starvation (Gajardo Tobar 1952, Pellegrino 1952, Dias 1965, Pratt \& Davey 1972, Costa \& Paranhos Perondini 1973, Friend \& Smith 1975, Costa et al. 1987, Costa \& Jurberg 1989, Gonçalves et al. 1989, Galvão et al. 1996, Canavoso \& Rubiolo 1998, Cortéz \& Gonçalves 1998, Costa \& Marchon-Silva 1998, Lorosa et al. 1999, Cabello 2001, Moreira \& Spata 2002, Gomes Dias-Lima \& Sherlock 2002), mating frequency, mating speed and duration of copulation (Lima et al. 1986). T. cruzi infections have also been related to nutritional indicators (Petersen et al. 2001), principally cleptohaematophagy, in some triatomine species (Sandoval et al. 2000). Only a few studies have focused on the quantitative estimation of feeding under natural conditions (Rabinovich et al. 1979, Lopez et al. 1999).

Describing kissing-bug blood-feeding patterns across vertebrate hosts is important for a better understanding of the epidemiology of $T$. cruzi and how it circulates among mammalian hosts. Ecological niche theory is applicable to the study of kissing-bug feeding patterns. By definition, the niche is the manner in which organisms or a population responds to the distribution of resources and other species (competitors, predators, parasites and pathogens). Niches have two components: position and breadth. Niche position characterises which resources are used by a particular species, i.e., presence/absence of certain hosts as a food source (for example, if the blood of a certain species of host is found in individuals of a given kissing-bug species), whereas niche breadth characterises the number of resources, i.e., the number or proportion of different host species in the diet of a given kissing-bug species (Brandle et al. 2002). In this sense, blood-feeding profiles can be used to estimate the niche breadth of kissing-bugs because studying field-caught bug species can quantify host use. Both niche position and niche breadth may be affected by climatic variability, habitat type and other constraints such as life history traits and phylogenetic conservatism (Sherry 1984).

Feeding patterns of kissing-bugs are typically studied in habitats of epidemiological importance: the domicile, the peridomicile and the wild (often called "sylvatic"). Habitat type can play a major role in kissing-bug feeding choices because preferences could be limited by host availability, as observed in mosquito vectors (Lefevre et al. 2009). In addition, species distributions tend to be nested, that is, species inhabiting a certain habitat may be a subset of species from another habitat (Kolasa 1996). Nestedness is a commonly observed pattern in nature in which small communities form proper subsets of large communities (Ulrich \& Gotelli 2007a, b, Ulrich et al. 2009). Thus, diet overlap across kissing-bug species could be limited by host species overlap across habitats, i.e., the degree of nestedness in host community composition could be reflected in the diet of kissing-bugs.

In this article, we present a study of the variation in niche breadth across kissing-bug species and their patterns of host co-feeding. We analysed the feeding profiles of kissing-bugs under natural conditions using data obtained exclusively by the precipitin test. We restricted our analysis to precipitin tests because this test has been the technique most widely used with kissing-bugs, given its relatively low cost and appropriate resolution to study host use at the level of families and orders. The precipitin test has been widely used for the identification of triatomine blood-meals since the 1960s (Rodriguez 1966) and its powerful sensitivity has been reported by several researchers (Wisnivesky-Colli et al. 1982, Lorosa et al. 1999, 2003). In addition, the precipitin test has the power to detect multiple meals, unlike more recent techniques based on DNA polymerase chain reaction (Hamer et al. 2009, Chaves et al. 2010), which have been used in a few instances to study kissing-bug blood-feeding patterns (Mota et al. 2007, Pizarro \& Stevens 2008). In our analysis, several analytical techniques were used to provide qualitatively different insights regarding the blood-feeding niche breadth of kissing-bugs. The null model test of host use (i.e., the null hypothesis that observed patterns result from random processes is assumed) was used to determine patterns of segregation, aggregation or randomness in host exploitation, i.e., whether kissing-bug species have strong preferences for certain host categories (segregation), if all kissing-bug species feed in the same host categories (aggregation), or if there are no patterns (random). However, such an analysis does not take full advantage of the compositional information from the relative abundance of different blood-sources to describe similarities in blood-feeding. To further exploit information on relative host use, multivariate analysis tools of ordination and clustering were used. The patterns of host co-feeding at the host class level and order/ family level within mammals in areas in which Chagas 
disease is zoonotic in 30 species of kissing-bugs were studied. The variability in the blood-feeding patterns of eight selected kissing-bug species that have major epidemiological importance for the transmission of $T$. cruzi, and for which samples were collected in several locations, was also studied. Additionally, the patterns of nestedness and clustering in habitat use by kissing-bug species were investigated, largely because such patterns could partially explain the patterns of blood-feeding choices. Finally, the results were evaluated in light of the eco-epidemiology of Chagas disease transmission.

\section{MATERIALS AND METHODS}

Data - The primary information for analysis was extracted from a unique and extensive triatomine database on the geographical distribution, life-history, diet and habitat of 116 triatomine species reported in the literature (Carcavallo et al. 1999). Over 500 bibliographic references were surveyed, of which 61 presented data on blood-feeding profiles. From these references, a subset 159 cases, representing 30 species, with reliable precipitin blood-feeding profiles from bugs sampled under natural conditions was obtained.

The extracted data were compiled in a Table (Supplementary data). For each of the 159 cases, the following was recorded: the triatomine species name, country of study, region of triatomine collection, number of individual insects analysed with the precipitin test, number of insects positive to each of the tested host antiserum and corresponding bibliographic source. The habitat type was categorised epidemiologically as domiciliary, peridomiciliary or sylvatic (wild).

Data were entered as the absolute number of collected insects that had been identified as feeding in one or more of the hosts. When a certain number of triatomine individuals showed the same mixed (multiple) feeds (e.g., four triatomines being positive to dogs, cats and humans), they were distributed to the corresponding individual feeding category in the same proportion as that in which the individual feeding categories were found (e.g., if individual feeds had been $25 \%$ on dogs, $25 \%$ on cats and $50 \%$ on humans, those 4 mixed feedings were distributed as follows: 1 to dogs, 1 to cats and 2 to humans). If the resulting numbers were not integers, they were rounded up.

From the data compilation, five matrices were constructed: 1: the full data matrix, as described in the Supplementary data; 2: the species-dominant habitat matrix (pooling the habitats collected in each study for each species and identifying the habitat with the higher per cent of use as the dominant habitat); 3: the host class species feeding profile matrix, in which the diet profile of each species was pooled, and the host groups were represented only at the host class level (Mammalia, Aves, Amphibia, Reptilia and Insecta); 4: the mammal feeding profile matrix, which is similar to 3 but with the host groups represented exclusively at the family and order level within the class Mammalia, with 13 families [Chiroptera, Hominidae (Human), Felidae, Canidae, Leporidae, Rodentia, Bovidae, Dasypodidae, Didelphidae, Equidae, Suidae, Myrmecophagidae, Bradypodi- dae, Hominidae (non human) and Mephitidae] and the order Rodentia; 5: the selected species feeding profile matrix, composed of eight kissing-bug species at the individual study level and 15 groups of hosts (the classes Aves, Reptilia and Amphibia and the 12 families of the class Mammalia). The eight kissing-bug species, Panstrongylus geniculatus, Panstrongylus megistus, Rhodnius neglectus, Rhodnius prolixus, Triatoma brasiliensis, Triatoma dimidiata, Triatoma infestans and Triatoma sordida. $R$. prolixus, T. brasiliensis, T. dimidiata and $T$. infestans were selected because they are the dominant vector species of $T$. cruzi transmission to humans. The other four kissing-bug species were added because they are abundant in diet profile studies (more than 6 cases) and are epidemiologically significant (they are usually considered in the secondary transmission of Chagas disease). P. geniculatus is of additional interest because, of all kissing-bug species, it has the largest geographical range (with a range area of approximately 12 million $\mathrm{km}^{2}$ in the New World). Matrices 2, 3, 4 and 5 were used for the different analyses described next.

Null model test - Co-occurrence of host feedings: C-score - The patterns of blood-feeding in kissing-bugs were studied using null model analysis, a technique that has been used in other disease vectors such as mosquitoes (Chaves et al. 2010). The C-score was used, which is an index that, in the context of this study, quantifies the overlap of host-use relative to the maximum possible overlap in a host community (Stone \& Roberts 1990). With the estimated C-score, the null hypothesis that kissing-bug species are equally likely to forage on a given host was tested. The $\mathrm{C}$-score of the original data matrix (kissing-bug species as rows and host as columns) was compared to the output of simulated matrices and inferences were made depending on the relationship of the $\mathrm{C}$-score of the original data to that of the simulations. When the original C-score was larger than that of the simulations for a given significance level, segregated feeding was inferred, i.e., a pattern of strict host-specific feeding. When the original $\mathrm{C}$-score was smaller than that of the simulations, the inference was made that all the kissing-bugs share at least one of the host-species in their blood-meals. When the original C-score was equal to the simulated C-score, host-use patterns were inferred to be random. The analysis was implemented by making simulated matrices of species (columns)-blood meal feeding profile (rows). The matrices were made with constant row sums, which assume a constant number of host types on which the kissing-bugs can feed, and equiprobable columns, which indicates an equal probability to feed on any of the host types. The fixed-equiprobable algorithm was chosen because it provides a robust predictor (Gotelli 2000) and although not the most powerful tool, it allows the testing of the null hypothesis of equal preference among host species. Simulations were conducted using the software Ecosim 7.0 (Gotelli 2000) and 5,000 randomisations were used for the tests.

Null model test - Nestedness in epidemiological habitat-use - Whether epidemiological habitat-use was nested was determined with the null model testing of a matrix 
of kissing-bug species (columns) vs. habitat (rows), using $\mathrm{NODF}_{\text {col }}$, a nestedness index based on overlap and decreasing fills of columns (Ulrich et al. 2009). The nestedness measure based on overlap and decreasing fills (NODF) is a method that aims to quantify independently whether (i) a community in a depauperate assemblage constitutes subsets of progressively richer communities and (ii) the less frequent species are found in subsets of the sites in which the percentage of occurrences in the right columns and the species in the inferior rows overlap with those found in left columns and upper rows with higher marginal totals for all pairs of columns and rows, respectively, most commonly occur (Almeida-Neto et al. 2008). A fixed-equiprobable algorithm was chosen, which tests whether the diversity of kissing-bug species observed in less species-rich epidemiological habitats is a subset of the species-richest habitat, i.e., with the highest number of species per habitat. Whether the nestedness pattern was non-random was tested using a standardised effect size test, in which a resulting absolute value of standardised nestedness above 2 (using the mean and standard deviation of the simulated matrices) indicates a significant pattern of nestedness (Ulrich et al. 2009).

Niche breadth - Niche width is a measure of the breadth or diversity of resources used by an individual or species (Magurran 1988). The Shannon diversity index is typically used for calculating niche width by simply replacing the number of resource categories observed (e.g., food types eaten) with the number of species in a community. Hutcheson (1970) and Bowman et al. (1971) suggested the following estimation formula for the Shannon index:

$$
H^{\prime}=-\sum p_{i} \ln p_{i}-\frac{S-1}{N}+\frac{1-\sum p_{i}^{-1}}{12 N^{2}}+\frac{\sum\left(p_{i}^{-1}-p_{i}^{-2}\right)}{12 N^{3}}
$$

where $p_{i}$ is the relative abundance of each blood-source species calculated as the proportion of individuals of a given species to the total number of individuals tested $(n / N) . n_{i}$ is the number of individuals of species $I$, i.e., the frequency of species $i$ in the diet $S$ is the number of taxonomic categories (or blood-source taxonomic categories richness) and $N$ is the total number of triatomine individuals tested.

However, Magurran (1988) suggested that, as shown by Peet (1974), the contribution of all of the terms of the series after the second are very small, so the following simplified version of the Shannon index was used:

$$
H^{\prime}=-\sum p_{i} \ln p_{i}-\frac{S-1}{N}
$$

where all symbols remain as described.

For the calculation of the Shannon diversity index and their $95 \%$ confidence intervals, the software PAST (Hammer et al. 2001) was used.

The issue of compositional data - Although the numbers of a kissing-bug species' feeding profile do not have any significant relevance, the relative abundance or composition can be compared across species, so that the distortion of raw numbers from the multivariate statistics may be avoided. However, using proportions as simple standardisation may distort the results of the multidimensional analysis (Jackson 1997). To avoid this problem, the matrices containing data on blood-feeding frequencies of kissing-bugs on certain host categories were transformed into compositional (relative quantity) data (Aitchison 1986). A composition analysis was performed on the D-1 dimensional simplex, in which the positive elements of a vector of dimension $\mathrm{D}$ sum to 1 , $\mathrm{D}$ is the number of hosts on which kissing-bug species can feed and compositions are the ratios in the data. This approach was preferred over the more conventional Aitchison log-ratio metric, given the limitation of logarithmic transformations in datasets with several proportions that are zero (Rehder \& Zier 2001), resulting from the absence of food sources across kissing-bugs species.

Principal component analysis - Principal component analysis is an ordination technique that allows for a summary of variability patterns in multidimensional datasets (Venables \& Ripley 2002). A principal component analysis on the matrices was performed by transforming them and obtaining compositional data, which are called "composition matrices". Here, the principal components were estimated from the matrix of variance-covariance computed from the composited matrices (Venables \& Ripley 2002).

Cluster analysis - Cluster analysis is a type of analysis in which elements in a dataset are arranged in groups or subsets based on their characteristics. In this study, the subsets (groups of species) are formed based on the similarity of host or habitat-use. A partition technique, partitions around medoids (PAM), was used in which a number of clusters is proposed a priori and can be selected based on the silhouette value, a measurement of the average similarity between any element (in our study, a kissing-bug species) in a given cluster when compared with the rest of the cluster elements (Kaufman \& Rousseeuw 1990). Results were confirmed by using an agglomerative hierarchical cluster technique in which elements (i.e., kissing-bug species) were iteratively joined with the most similar elements during iterative steps of a joining algorithm. For the clustering, a complete linkage algorithm was used that aimed to find very similar clusters (Kaufman \& Rousseeuw 1990).

Multiple correspondence analysis - The pattern of association of the two clustering methods and the dominant habitat of a kissing-bug species was studied using a multiple correspondence analysis. This type of analysis is a multivariate analysis performed on more than two categorical variables and can be used to determine patterns of association between the studied variables. The outcome of this analysis is a set of coordinates that indicate the association between the different categories and the different elements (in this study, elements are kissing-bug species). The closer that two coordinates are in space, the more associated that the categories or elements are that they represent. Here, multiple correspondence analysis was implemented using a singular value decomposition of a Burt matrix with an adjustment of inertias (Nenadic \& Greenacre 2007). 


\section{RESULTS}

The bibliographic compilation on feeding sources of triatomines resulted in 30 species, representing seven genera (13 of Triatoma, 6 of Panstrongylus and Rhodnius, 2 of the genus Belminus and 1 of the genera Cavernicola, Mepraia and Psammolestes).

Blood-meal sources of our 29 triatomine species include five taxonomic classes (Mammalia, Aves, Amphibia, Reptilia and Insecta). Mammals were differentiated using the precipitin tests in 14 families [Chiroptera, Hominidae (Human), Felidae, Canidae, Leporidae, Bovidae, Dasypodidae, Didelphidae, Equidae, Suidae, Myrmecophagidae, Bradypodidae, Hominidae (non human) and Mephitidae] and the order Rodentia. In total, 19 taxonomic host categories were used to identify blood-source.

The 159 cases provided data from a total of 39,520 feeds that were grouped into three habitats (and their combinations): sylvatic (wild), domiciliary and peridomiciliary. Table I shows the grouping of each of the 30 kissing-bug species by dominant habitat-use. In the nestedness analysis of epidemiological habitat-use, a NOD$\mathrm{F}_{\text {col }}$ of 64.23 was estimated and because the simulation average was 56.02 with a standard deviation of 10.58 , it was concluded that the nestedness of habitat-use is ran$\operatorname{dom}(Z=0.78, \mathrm{p}>0.05)$.

Table II shows the patterns of co-feeding using the $\mathrm{C}$-score method for the different dominant habitats and the blood-feeding data grouped at the five taxonomic classes. Estimated C-score values were calculated from the data and the mean \pm variance values were the results from the simulations. With the exception of the "peridomicile and/or sylvatic" habitat for which results were random, all habitat-use patterns were aggregated when hosts were analysed at the class level.

TABLE I

Dominant habitat types used by the 30 kissing-bug species analyzed

\begin{tabular}{|c|c|c|c|c|c|c|}
\hline \multirow[b]{2}{*}{ Kissing-bug species } & \multicolumn{6}{|c|}{ Dominant habitat } \\
\hline & SYL & PER & DOM & SYL-PER & PER-DOM & SYL-PER-DOM \\
\hline Cavernicola pilosa & $\mathrm{X}$ & & & & & \\
\hline Panstrongylus lignarius & $\mathrm{X}$ & & & & & \\
\hline Panstrongylus geniculatus & $\mathrm{X}$ & & & & & \\
\hline Rhodnius neglectus & $\mathrm{X}$ & & & & & \\
\hline Rhodnius pictipes & $\mathrm{X}$ & & & & & \\
\hline Triatoma longipennis & & $\mathrm{X}$ & & & & \\
\hline Triatoma maculata & & $\mathrm{X}$ & & & & \\
\hline Belminus ferroae & & & $\mathrm{X}$ & & & \\
\hline Belminus herreri & & & $\mathrm{X}$ & & & \\
\hline Panstrongylus herreri & & & $\mathrm{X}$ & & & \\
\hline Panstrongylus lutzi & & & $\mathrm{X}$ & & & \\
\hline Triatoma pallidipennis & & & $\mathrm{X}$ & & & \\
\hline Triatoma vitticeps & & & $\mathrm{X}$ & & & \\
\hline Mepraia spinolai & & & & $\mathrm{X}$ & & \\
\hline Panstrongylus megistus & & & & & $\mathrm{X}$ & \\
\hline Triatoma costalimai & & & & & $\mathrm{X}$ & \\
\hline Rhodnius pallescens & & & & & $\mathrm{X}$ & \\
\hline Triatoma barberi & & & & & $\mathrm{X}$ & \\
\hline Triatoma dimidiata & & & & & $\mathrm{X}$ & \\
\hline Triatoma brasiliensis & & & & & $\mathrm{X}$ & \\
\hline Triatoma infestans & & & & & $\mathrm{X}$ & \\
\hline Triatoma pseudomaculata & & & & & $\mathrm{X}$ & \\
\hline Triatoma rubrofasciata & & & & & $\mathrm{X}$ & \\
\hline Triatoma sordida & & & & & $\mathrm{X}$ & \\
\hline Rhodnius ecuadoriensis & & & & & $\mathrm{X}$ & \\
\hline Rhodnius nasutus & & & & & & $\mathrm{X}$ \\
\hline Panstrongylus tupynambai & & & & & & $\mathrm{X}$ \\
\hline Psammolestes tertius & & & & & & $\mathrm{X}$ \\
\hline Rhodnius prolixus & & & & & & $\mathrm{X}$ \\
\hline Triatoma rubrovaria & & & & & & $\mathrm{X}$ \\
\hline
\end{tabular}

DOM: domiciliary; PER: peridomiciliary; SYL: sylvatic. 
TABLE II

Patterns of host class co-feeding

\begin{tabular}{lcccccc}
\hline Habitats & Number of species & C-score & Mean \pm variance & $\mathrm{p}<\exp$ & $\mathrm{p}>\exp$ & Pattern \\
\hline All & 30 & 0.258 & $1.457 \pm 0.004$ & 1 & 0 & Aggregated \\
Domicile and/or peridomicile & 11 & 0.527 & $1.238 \pm 0.040$ & 1 & 0 & Aggregated \\
Peridomicile and/or sylvatic & 4 & 0.167 & $0.082 \pm 0.007$ & 1 & 0.49 & Random \\
Domicile, peridomicile and sylvatic & 15 & 0.029 & $1.491 \pm 0.020$ & 1 & 0 & Aggregated \\
\hline
\end{tabular}

habitat indicates the different habitats where bugs were sampled. Estimated C-score values are calculated from the data. Mean \pm variance is the results from the simulations. The values of $p<\exp$ and $p>\exp$ indicate the probability that the C-score value is significantly smaller (indicating aggregated pattern) or larger (segregated pattern) than that expected (exp) by random, respectively. $\mathrm{p}$ value $<0.05$ indicates statistical significance and so the pattern is random. Pattern indicates the interpretation of the pattern.

TABLE III

Patterns of mammal host co-feeding

\begin{tabular}{lcccccc}
\hline Habitats & Number of bug species & C-score & Mean \pm variance & $\mathrm{p}<\exp$ & $\mathrm{p}>\exp$ & Pattern \\
\hline All & $28^{a}$ & 2.788 & $9.683 \pm 0.092$ & 1 & 0 & Aggregated \\
Domicile and/or peridomicile & 9 & 1.444 & $5.800 \pm 0.430$ & 1 & 0 & Aggregated \\
Peridomicile and/or sylvatic & 4 & 4.333 & $3.756 \pm 0.196$ & 0.98 & 0.10 & Random \\
Domicile, peridomicile and sylvatic & 15 & 3.220 & $10.739 \pm 0.390$ & 1 & 0 & Aggregated
\end{tabular}

$a$ : the number of kissing-bug species is reduced to 28 because samples from Belminus herreri and Panstrongylus lignarius fed only on insects and birds, respectively. This Table is similar to Table II, but with the analysis restricted to mammal families and the order Rodentia. Columns and identification of results are the same as for Table II.

Table III is similar to Table II but with the analysis restricted to mammal families (and to the order Rodentia) to establish the patterns of host co-feeding. Again, as with the host class level, with the exception of the "peridomicile and/or sylvatic" habitat for which results were random, all habitat-use patterns were aggregated when hosts were analysed at the mammal family (and order Rodentia) level.

The results of the various multivariate analyses of blood-feeding patterns at the host class level are shown in Fig. 1. In general, results robustly show three main host types that kissing-bugs more frequently feed on: insects, birds and mammals. The first two components explain more than $99 \%$ of the variability. The $\mathrm{x}$ axis presents the first component, which explains $66.77 \%$ of the variability. On this axis, positive values represent more frequent feedings on mammal hosts, while negative values represent more frequent feedings on avian hosts. The $\mathrm{y}$ axis presents the second component, which explains $32.83 \%$ of the variability, with positive values representing feedings on insects. Fig. 1B shows the PAM clusters. A clustering in three groups had the best fit, with an average silhouette $(h)$ of 0.71 (with 1 as the possible maximum). This clustering separates kissing-bugs species into three main groups: those that primarily feed on other insects (Belminus herreri and Belminus ferroae), those that primarily feed on birds (Panstrongylus lignarius, Psammolestes tertius, Rhodnius ecuadoriensis, Rhodnius nasutus, $R$. neglectus, T. brasiliensis, Triatoma longipennis, Triatoma maculata, Triatoma pseudomaculata and T. sordida) and those that primarily feed on mammals (Cavernicola pilosa, Mepraia spinolai, P. geniculatus, Panstrongylus herreri, Panstrongylus lutzi, Panstrongylus megistus, Panstrongylus tupynambai, Rhodnius pallescens, Rhodnius pictipes, $R$. prolixus, Triatoma barberi, Triatoma costalimai, T. dimidiata, T. infestans, Triatoma pallidipennis, Triatoma rubrofasciata, Triatoma rubrovaria and Triatoma vitticeps). Fig. $1 \mathrm{C}$ shows the results of the agglomerative hierarchical cluster analysis. This clustering technique also produced three clear clusters (at a height of 0.6 ) in which species correspond to those identified with the partitions around medoids. It is worth noticing that there is no habitat overlap because the different dominant habitats overlap in the different clusters. Fig. 1D shows the results of the multiple correspondence analysis; the two axis represent $93.5 \%$ of the variability $(61 \%$ by axis $\mathrm{x}$ and $32.5 \%$ by axis y). The domiciliary habitat is most associated with feeding on insects (Fig. 1A) and is separated from the peridomiciliary habitat along the $\mathrm{x}$ axis. Both of these habitats are separated from the sylvatic species along the y axis. The peridomiciliary habitat is associated with more frequent feeding on birds (Fig. 1B) and species that colonise all habitats (sylvatic, peridomicilary and domiciliary) are associated with more frequent feeding on mammals (Fig. 1C). Species with other patterns of 


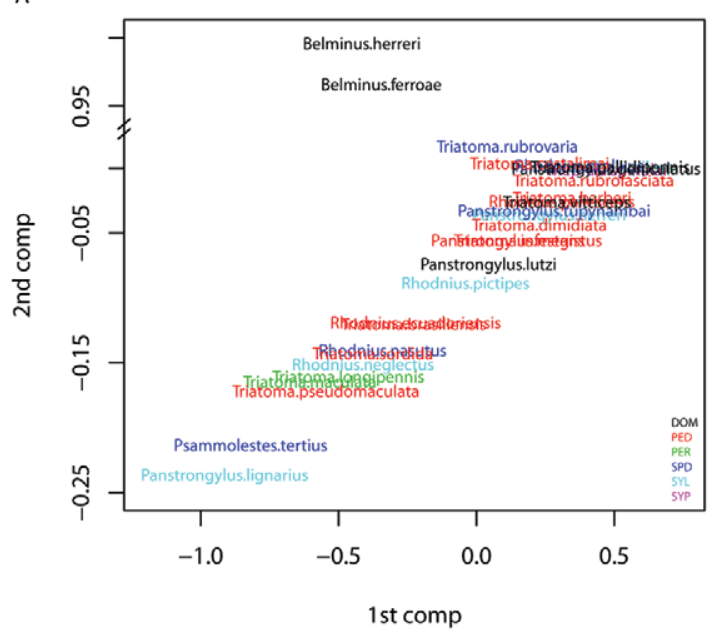

C

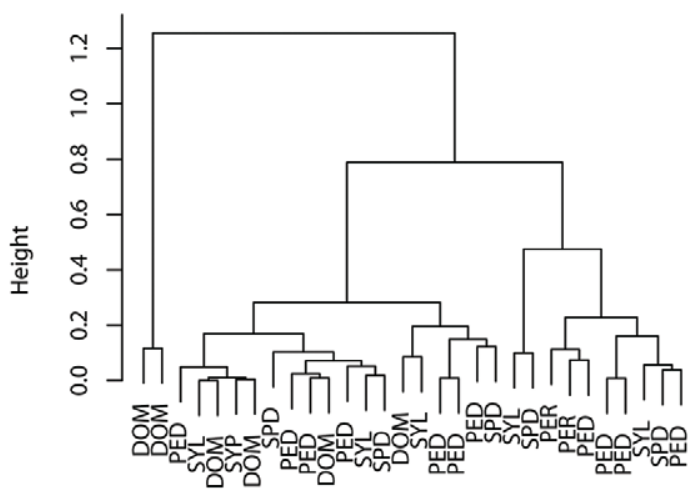

B

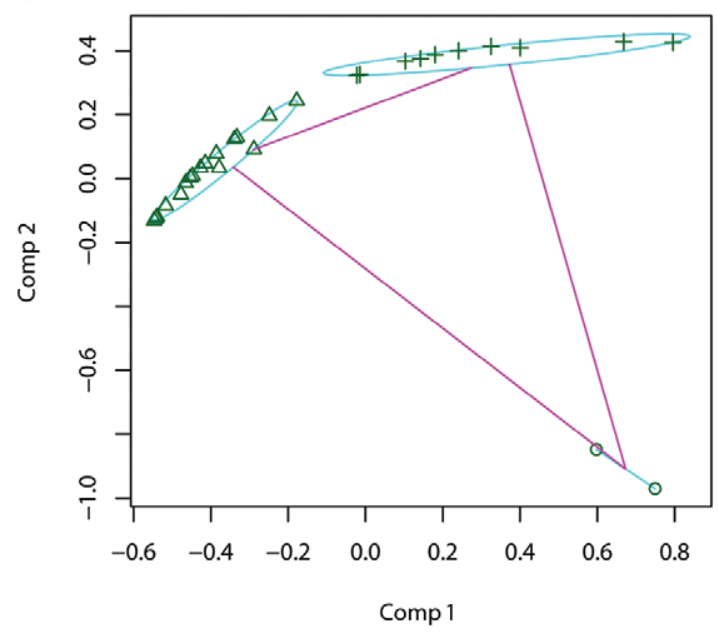

D

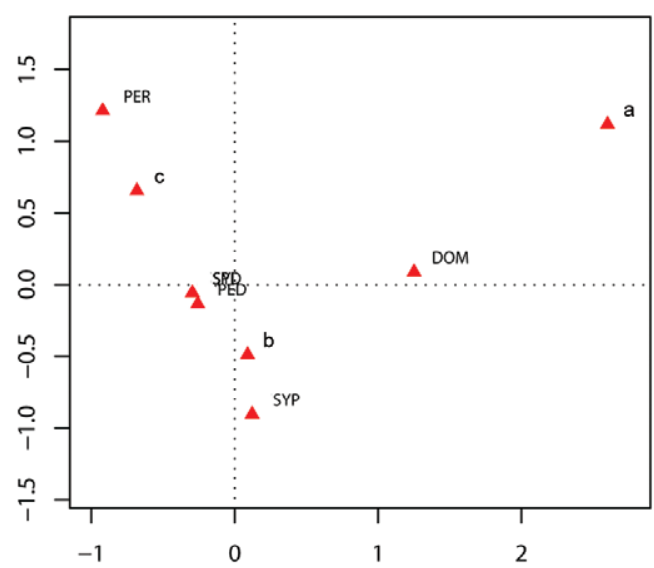

Fig. 1: multivariate analysis of kissing-bug species blood-feeding patterns at the class level (Aves, Mammalia, Amphibia, Reptilia and Insecta). A: principal component (comp) analysis. On the $\mathrm{x}$ axis positive values represent more frequent feedings on mammal hosts, while negative values represent more frequent feedings on avian hosts. On the y axis positive values represent feedings on insects. Colours indicate the habitats where kissing-bugs were sampled; B: partitions around medoids clusters. o: species that primarily feed on other insects (Belminus herreri and Belminus ferroae); +: species that primarily feed on birds (see text for the listing of the species); $\Delta$ : species that primarily feed on mammals (see text for the listing of the species); C: agglomerative hierarchical cluster analysis. Three clear clusters can be seen at a height of 0.6; D: multiple correspondence analysis \{a: species most associated with feeding on insects [in the domiciliary (DOM) habitat]; b: species most associated with more frequent feeding on birds [in the peridomicilary (PER) habitat]; c: species most associated with more frequent feeding on mammals (and that colonize all habitats)\}. PED: PER + DOM; SPD: sylvatic (SYL) + PER + DOM; SYP: SYL + PER.

habitat-use do not seem to be specifically associated with any class of blood-source because they are close to the origin (coordinates $\mathrm{x}=0$ and $\mathrm{y}=0$ in the plot).

Fig. 2 shows results similar to Fig. 1 but in relation to the blood-feeding patterns on mammals. In general, the major divisions were between humans, canids and rodents vs. didelphids (i.e., opossums and related organisms). In Fig. 2A, the first two components explain approximately $53 \%$ of the variability; the $\mathrm{x}$ axis (the 1st component) explains $30.78 \%$ of the variability, with positive values representing more feedings on humans, dogs and rodents hosts, while negative values represent more frequent feedings on didelphids. The y axis (the 2nd component) explains $22.02 \%$ of the variability, with positive values representing feeding on rodents and didelphids. Fig. 2B shows the PAM clusters; a cluster with four medoids had the best fit, with an $h$ of 0.52 (being 1 the maximum possible). With this method, kissing-bug species are separated into four main groups: those that primarily feed on didelphids (Ps. tertius, $R$. nasutus, $R$. neglectus and $R$. pictipes), those with a more diverse diet that included some rodents; those that feed primarily on humans and rodents (P. megistus, $R$. pallescens, $R$. prolixus, $T$. brasiliensis, T. infestans, T. pallidipennis and T. pseudomaculata) and those that feed primarily on rodents and didelphids $(M$. spinolai, $P$. herreri, $P$. lutzi, $P$. tupynambai, $R$. ecuadoriensis, T. barberi, T. costalimai, T. dimidiata, T. maculata, T. rubrofasciata and T. sordida). Fig. $2 \mathrm{C}$ shows the results of the agglomerative hierarchical cluster analysis; this clustering technique also produced four clear clusters (at a height of about 0.4) in which species correspond to those identified with the partitions around medoids. 
A

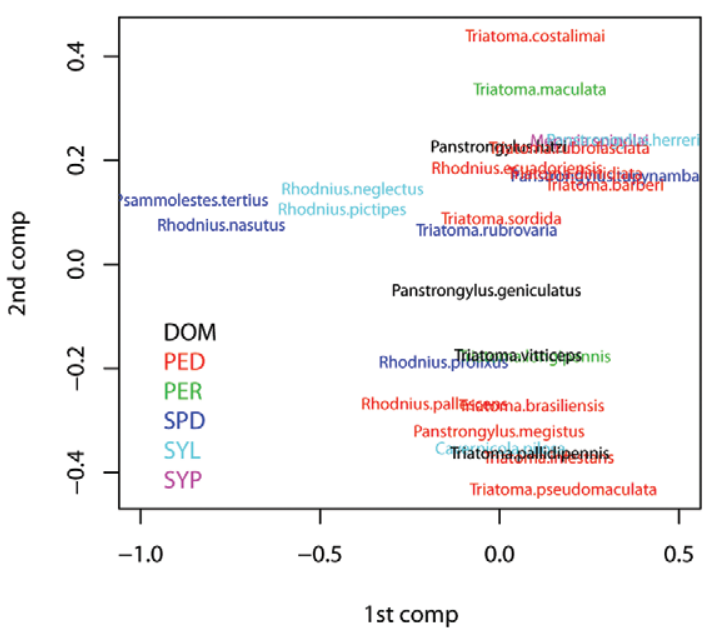

C

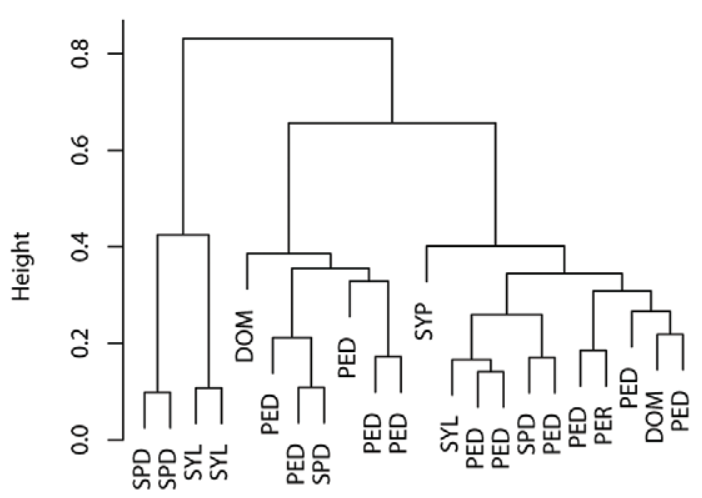

B

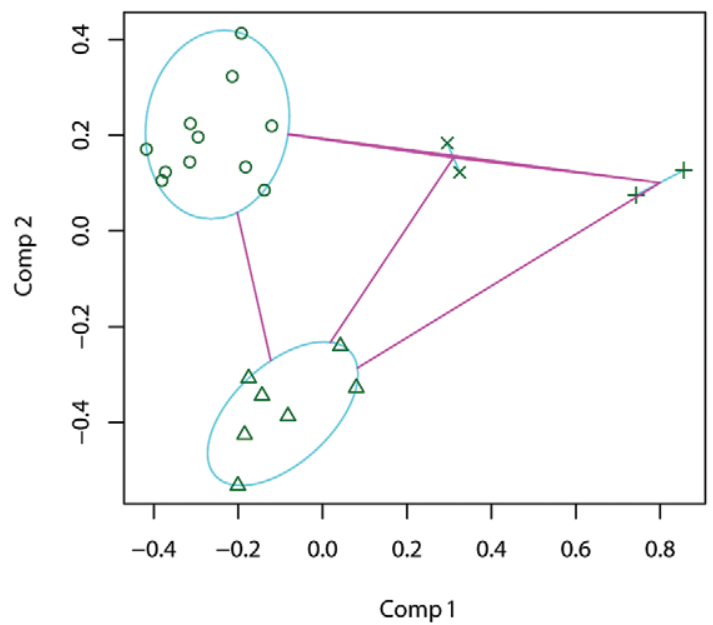

D

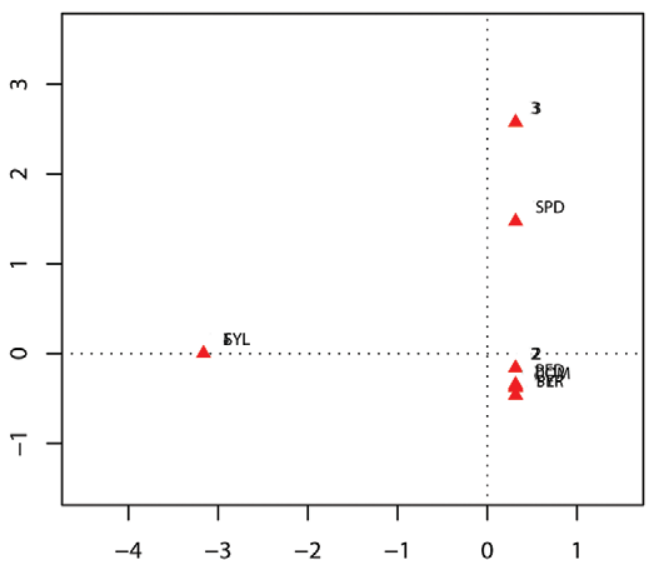

Fig. 2: multivariate analysis of kissing-bug species blood-feeding patterns related to mammals (family level and order Rodentia). A: principal component (comp) analysis. The first two components explain about $53 \%$ of the variability. Colours indicate the habitats where bugs were sampled; B: partitions around medoids clusters; C: agglomerative hierarchical cluster analysis, with four clear clusters (at a height of about 0.4); D: multiple correspondence analysis. The sylvatic habitat is strongly related to the feeding on didelphids (identified as 4) and the use of all habitats. In 3 are the species associated with feeding on humans and rodents. DOM: domiciliary; PED: peridomiciliary (PER) + DOM; SPD: sylvatic (SYL) + PER + DOM; SYP: SYL + PER.

Fig. 2D shows the results of the multiple correspondence analysis. The two axes represent $80.1 \%$ of the variability ( $49.5 \%$ by the $\mathrm{x}$ axis and $30.5 \%$ by the $\mathrm{y}$ axis). Most species with other patterns of habitat-use do not seem to be particularly associated with any category of blood-source because they are close to the origin (coordinates $x=0$ and $y=0$ ) (Fig. 2D). In summary, there is a clear habitat segregation because the different dominant habitats overlap in the different clusters. Most feeding choices were not associated with a particular habitat, but kissingbugs colonising all epidemiological habitats (domiciliary, peridomiciliary and sylvatic) tended to feed on humans, while the sylvatic kissing-bugs fed on didelphids. For the feeding patterns on mammals, the following species were not considered: C. pilosa, P. geniculatus, T. longipennis, $T$. rubrovaria and $T$. vitticeps. These species had a relatively small sample size and behaved as outliers that distorted the multivariate analysis. It is worth noticing that
C. pilosa is a kissing-bug species that inhabits caves and feeds exclusively on bats, while the other species have a very diverse and even resource use.

Fig. 3 shows the results for eight selected species that have epidemiological importance and were most widely sampled for their feeding source. Fig. 3A shows the results of the principal component analysis. The first two components explain slightly above $71 \%$ of the variability; $51 \%$ was explained by the $\mathrm{x}$ axis (positive values represent more frequent feeding on rodents and didelphids, while negative values represent a more frequent feeding on humans, bovids and canids) and $20 \%$ of the variability was explained by the y axis (positive values represent feedings on humans and didelphids). Fig. 3B shows the results of the partitions around the medoids clusters method; a clustering of three groups had the best_fit, with an $h$ of 0.5 (with 1 as the possible maximum). Fig. $3 \mathrm{C}$ shows the results of the agglomerative hierarchical cluster analysis; this tech- 
A

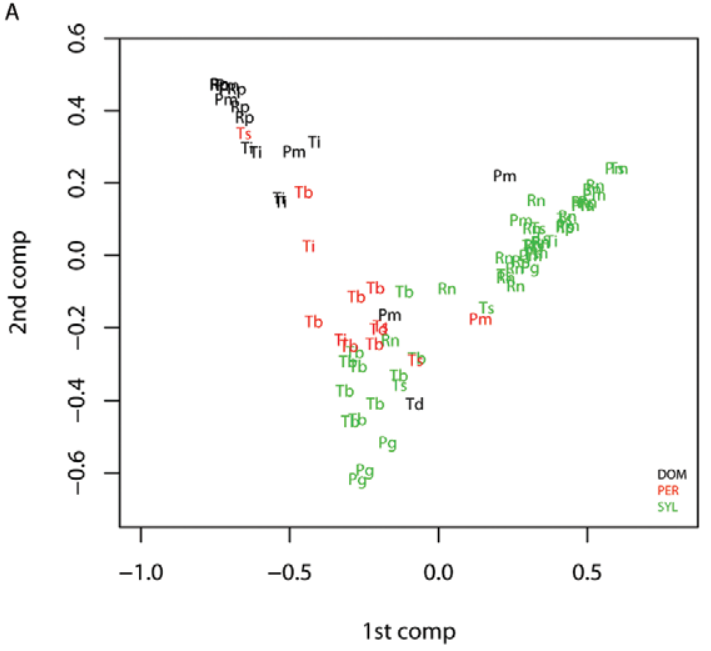

C

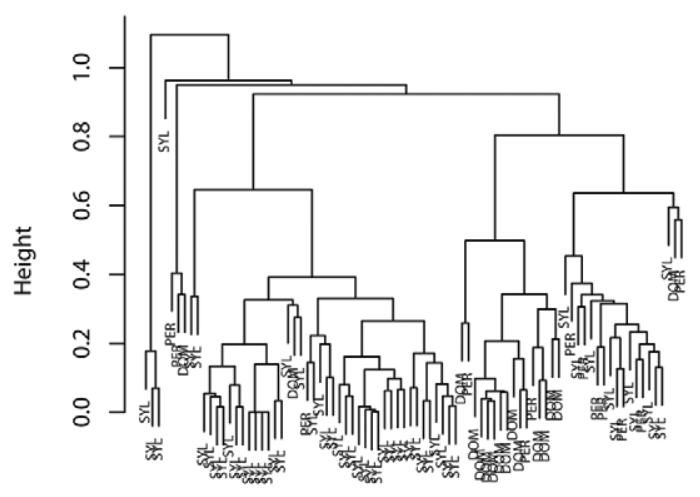

B

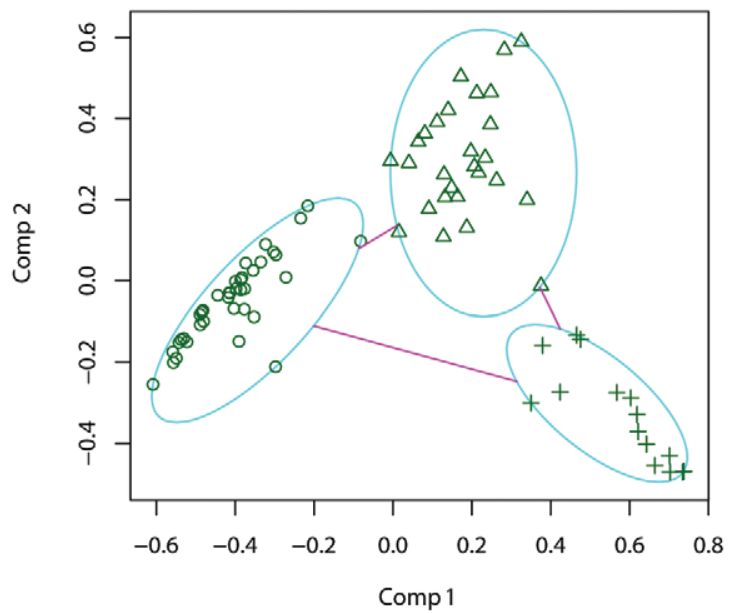

D

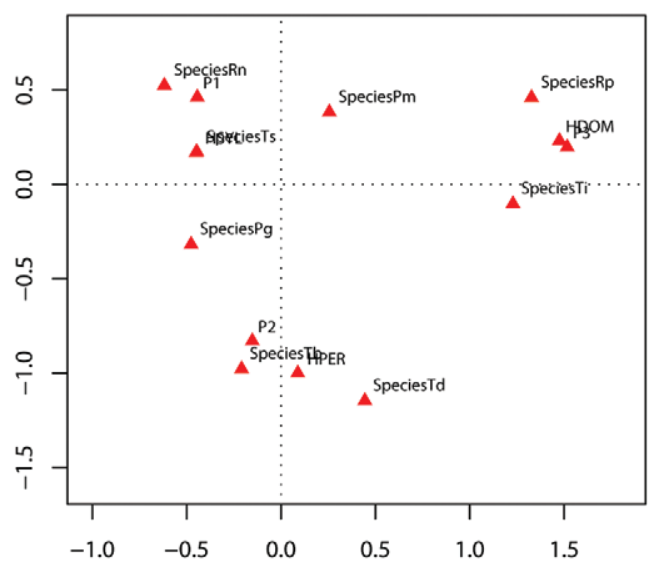

Fig. 3: multivariate analysis of eight selected kissing-bug species blood-feeding patterns related to mammals (family level and order Rodentia). The selected species are: Rhodnius prolixus (Rp), Triatoma dimidiata (Td), Triatoma infestans (Ti), Triatoma brasiliensis (Tb), Panstrongylus geniculatus (Pg), Rhodnius neglectus (Rn), Panstrongylus megistus ( $\mathrm{Pm})$ and Triatoma sordida (Ts). See Materials and Methods for the criteria of selection. A: principal component (comp) analysis. The first two components explain slightly above $71 \%$ of the variability, with colours indicating the dominant habitats where bugs were sampled in a given study (DOM: domiciliary; PER: peridomiciliary; SYL: sylvatic); B: partitions around medoids clusters. A clustering of three groups had the best fit, with an average silhouette $(h)$ of 0.5 ; C: agglomerative hierarchical cluster analysis. There are three clear clusters (at a height of 0.8); D: multiple correspondence analysis. The two axes represent $94 \%$ of the variability.

nique also produced three clear clusters (at a height of 0.8 ) in which species correspond to those identified with the partitions around medoids. There is a clear habitat segregation; outliers can be present in any habitat, but one group is clearly present in more sylvatic habitats, while the rightmost cluster is primarily present in domiciliary and peridomiciliary environments. Fig. 3D shows the results of the multiple correspondence analysis; the two axes represent $94 \%$ of the variability $(60 \%$ by the $\mathrm{x}$ axis and $34 \%$ by the y axis). The sylvatic habitat is strongly related to the feeding on didelphids (identified as P1) and the species $T$. sordida and $R$. neglectus. The domiciliary habitat is strongly related to the feeding on humans and canids and $T$. infestans and $R$. prolixus. The peridomiciliary habitat is related to more frequent feeding on rodents and canids and T. dimidiata and T. brasiliensis. P. megistus and $P$. geniculatus do not seem to be strongly associated with any habitat nor feeding source because they are close to the origin (coordinates $\mathrm{x}=0$ and $\mathrm{y}=0$ ). In summary, for these eight selected species of epidemiological importance, the clusters around habitats indicate that colonised habitats could be a template for feeding. Domiciliary bugs tended to feed primarily on humans and canids (i.e., dogs), while peridomiciliary bugs fed on rodents and dogs. The most important vector species were primarily associated with the domiciliary habitat ( $R$. prolixus and T. infestans) or peridomiciliary habitat (T. dimidiata and T. brasiliensis).

Table IV ranks, in increasing order, the niche breadth of the 30 kissing-bug species for the Shannon diversity index. In the Shannon index, the following eight species were in the lower quartile of feeding diversity: C. pilosa, $P$. lignarius, $P$. tertius, B. ferroae, B. herreri, P. geniculatus, . longipennis and $R$. nasutus, while another eight species were found to be in the upper quartile of feeding diversity: T. barberi, P. megistus, $R$. prolixus, T. infestans, P. lutzi, T. dimidiata, T. vitticeps and T. rubrovaria. 


\section{TABLE IV}

Niche breadth estimates based on the Shannon diversity index for the 30 species of kissing-bugs from all habitats pooled, ranked from smallest to largest

\begin{tabular}{lccccc}
\hline Species & $\mathrm{n}$ & $\mathrm{S}$ & Shannon & Lower & Upper \\
\hline Belminus herreri & 76 & 1 & 0 & 0 & 0 \\
Cavernicola pilosa & 17 & 1 & 0 & 0 & 0 \\
Panstrongylus lignarius & 6 & 1 & 0 & 0 & 0 \\
Psammolestes tertius & 51 & 3 & 0.319 & 0.096 & 0.522 \\
Belminus ferroae & 121 & 4 & 0.363 & 0.179 & 0.522 \\
Panstrongylus geniculatus & 178 & 5 & 0.659 & 0.504 & 0.785 \\
Triatoma longipennis & 113 & 3 & 0.694 & 0.559 & 0.783 \\
Rhodnius nasutus & 278 & 4 & 0.810 & 0.727 & 0.881 \\
Triatoma pseudomaculata & 3,789 & 10 & 0.859 & 0.823 & 0.892 \\
Triatoma maculata & 435 & 10 & 0.976 & 0.854 & 1.079 \\
Rhodnius neglectus & 4,982 & 9 & 1.059 & 1.033 & 1.084 \\
Panstrongylus herreri & 77 & 5 & 1.202 & 0.996 & 1.326 \\
Rhodnius ecuadoriensis & 8 & 4 & 1.213 & 0.376 & 1.321 \\
Panstrongylus tupynambai & 7 & 4 & 1.277 & 0.410 & 1.352 \\
Mepraia spinolai & 109 & 7 & 1.388 & 1.194 & 1.514 \\
Rhodnius pictipes & 106 & 8 & 1.419 & 1.196 & 1.557 \\
Triatoma sordida & 8,764 & 13 & 1.424 & 1.396 & 1.450 \\
Triatoma costalimai & 321 & 7 & 1.439 & 1.331 & 1.518 \\
Rhodnius pallescens & 1,683 & 13 & 1.444 & 1.392 & 1.488 \\
Triatoma rubrofasciata & 548 & 7 & 1.475 & 1.400 & 1.537 \\
Triatoma pallidipennis & 18 & 7 & 1.519 & 0.854 & 1.721 \\
Triatoma brasiliensis & 1,430 & 10 & 1.566 & 1.509 & 1.620 \\
Triatoma barberi & 958 & 12 & 1.574 & 1.506 & 1.629 \\
Panstrongylus megistus & 6,872 & 11 & 1.584 & 1.561 & 1.606 \\
Rhodnius prolixus & 1,071 & 10 & 1.587 & 1.526 & 1.634 \\
Triatoma infestans & 5,282 & 11 & 1.596 & 1.572 & 1.617 \\
Panstrongylus lutzi & 79 & 8 & 1.696 & 1.474 & 1.819 \\
Triatoma dimidiata & 751 & 14 & 1.705 & 1.625 & 1.765 \\
Triatoma vitticeps & 79 & 9 & 1.980 & 1.754 & 2.071 \\
Triatoma rubrovaria & 847 & 11 & 2.221 & 2.178 & 2.251 \\
\hline intber ofinsectsed & & & & & \\
\hline
\end{tabular}

$\mathrm{n}$ : number of insects used for the precipitin method; S: number of taxa used as food-source for each triatomine species; lower and upper: refer to the $95 \%$ confidence limits by bootstrap.

\section{DISCUSSION}

Although experimental trials have shown that some kissing-bug species can have strong preferences for a particular host when given a choice (Gurtler et al. 2009, Guerenstein \& Lazzari 2009), it is clear that outcomes are dependent on the ecological context of foraging. The analysis here supports a scenario of high plasticity in the patterns of host-use by kissing-bugs, which, in the ecological context of blood-foraging and primarily defined by the availability of hosts in the environments colonized by these vectors, could explain the patterns of host use. This pattern has been very well-studied for some species, with the most comprehensive studies having been conducted with $T$. infestans in which both surveys and experiments have shown that the density of bugs and hosts plays a major role on the patterns of hostuse (Wisnivesky-Colli et al. 1982, Gurtler et al. 1997, 2009). But the pattern is common to other species, such as T. longipennis, which in Mexico has been shown to diversify its food sources and disperse following habitat modifications (Breniere et al. 2004, Bosseno et al. 2009). The catholic host-use is a pre-condition for the emergence of vector-borne zoonotic diseases (Levins et al. 1994, Chaves et al. 2010). This observation in kissingbugs is important because plans to control Chagas disease transmission via the suppression of dominant vector species could prove inefficient in the long-term and because other kissing-bug species that have similar feeding profiles could, in principle, transmit $T$. cruzi. The importance of the possible feeding source and mixed feedings in triatomines in terms of fecundity and fertility has been shown by Aldana et al. (2009) with $R$. prolixus.

This study also shows the urgent need to expand the focus of kissing-bug blood-foraging studies from that centred around the dominant vector species to the entire community of kissing-bug species. This expansion is necessary for several reasons: it can provide insights into the vectorial potential of species that are not currently considered as important vectors (Canale et al. 2000); it can increase knowledge on the diversity of the subfamily Triatominae (Hutchinson 1941, 1959, Colwell \& Coddington 1994, Colwell \& Hurtt 1994); and it can provide insights about the ecological determinants of kissing-bug blood-foraging. For example: are patterns driven by interspecific interactions or by habitat colonisation (Chaves \& Añez 2004)? Do species share hosts at the local habitat scale or do the preferences translate into patterns of segregation in host-use (Chaves et al. 2010)? The type of multivariate analysis conducted in this study can be very useful to study feeding patterns in kissing-bugs and other vectors at the population and community levels.

Although the analysis was restricted to the epidemiologically important habitat categories [the domicile, peridomicile and sylvatic (i.e., wild) habitat that encompasses all other habitats], there are other relevant criteria to include in future studies, including the details of the feeding profile within the sylvatic ecotopes. For example, it is known that virtually all species of the genus Rhodnius are primarily associated with palms, the genus Panstrongylus with burrows and tree cavities and the genus Triatoma with terrestrial rocky habitats or rodent burrows (Gaunt \& Miles 2000). Considering the rapid adaptation to new environments and the accelerated process of domiciliation by many kissing-bug species (Noireau et al. 2005), future studies will need to define "sylvatic" habitats using more ecologically sound criteria because, from the kissing-bug perspective, some of these habitats could be considered more peridomiciliary than sylvatic. Ecologically based categories for peridomiciliary habitat classification are also necessary because, for some kissing-bug species, the peridomicile could be considered sylvatic because species are not colonizing new habitats; however, humans are becoming part of the kissing-bug species natural habitat. 
In the early 1960s, it was commonly assumed that only some kissing-bug species were able to transmit parasites across certain habitats and host-species (Barretto et al. 1966, Barretto 1968). This perception was reinforced by the association of some hosts with T. cruzi discrete typing units (Zingales et al. 2009) and the untested assumption that these patterns are shaped by feeding preferences, which in some cases are assumed to be genetically determined due to fitness differences associated with feeding sources (Piesman et al. 1983, Acuña-Retamar et al. 2009). However, one of the evolutionary expectations for organisms living in changing environments is the absence of specialisation when, for example, resources are not constant or differences in quality are small from the perspective of the consumer (Levins 1968). Thus, uncertainty in resource-use, or the lack of major differences in nutritional blood quality from different hosts could explain the apparent lack of host-specialisation in kissing-bugs, which might be further supported by the monophyly of the Triatominae as a sub-family and the evolutionary time since their divergence (Gaunt \& Miles 2000, Patterson \& Gaunt 2010). Future studies in which phylogenetic and ecological information are considered together should be further explored (Vamosi et al. 2009).

The analysis of kissing-bug species feeding profiles and phylogenetic information will also allow the testing of a hypothesis suggested by Aragão (1983) that colonisation of new habitats by kissing-bug species is driven by the vertebrate classes inhabiting such habitats. Aragão (1983) proposed this hypothesis based on the observation that blood-meals in kissing-bugs species collected in different habitats were correlated with the abundance and ubiquity of host-species across the colonised habitats. In this sense, these results are encouraging because some species, for example B. herreri and P. lignarius, have restricted sets of host-species, indicating a potentially very specialised niche, but also limited sampling in the studies we analysed (Teixeira et al. 2001, Sandoval et al. 2004). Gaunt and Miles (2000) suggested that these types of species (as well as Microtriatoma trinidadensis, Eratyrus mucronatus and Triatoma tibiamaculata) remained in a relatively primitive feeding stage and did not follow the "recent dramatic spread of a few eclectic, domiciliated triatomine species".

Finally, given the positive association between kissing-bug habitat colonisation and host use, our results imply that control measurements directed at disrupting the contact between humans and kissing-bugs, especially housing improvement (Briceño-León 1990), are among the most desirable strategies for Chagas disease control.

\section{ACKNOWLEDGEMENTS}

To Ms Soledad Ceccarelli, for her help in the final formatting of the manuscript.

\section{REFERENCES}

Abad-Franch F, Aguilar VHM, Paucar CA, Lorosa ES, Noireau F 2002. Observations on the domestic ecology of Rhodnius ecuadoriensis (Triatominae). Mem Inst Oswaldo Cruz 97: 199-202.

Abad-Franch F, Monteiro FA, Jaramillo ON, Gurgel-Goncalves R, Dias FBS, Diotaiuti L 2009. Ecology, evolution, and the long-term sur- veillance of vector-borne Chagas disease: a multi-scale appraisal of the tribe Rhodniini (Triatominae). Acta Tropica 110: 159-177.

Acuña-Retamar M, Botto-Mahan C, Canals M, Correa JP, Cattan PE 2009. Comparative population dynamics of the bug Mepraia spinolai, a sylvatic vector of Chagas' disease in different hosts. Med Vet Entomol 23: 106-110.

Aitchison J 1986. The statistical analysis of compositional data monographs on statistics and applied probability, 1st ed., Chapman \& Hall, London, $416 \mathrm{pp}$.

Aldana E, Jácome D, Lizano E 2009. Efecto de la alternación de fuentes sanguíneas sobre la fecundidad y la fertilidad de Rhodnius prolixus Stål (Heteroptera: Reduviidae). Entomo Brasilis 2: 17-23.

Aldana E, Lizano E, Rodríguez M, Valderrama A 2001. Alimentación y defecación en triatominos del género Rhodnius (Hemiptera: Reduviidae) alimentados con sangre humana. Rev Biol Trop 49: 693-696.

Almeida CE, Duarte R, Guerra do Nascimento R, Pacheco RS, Costa J 2002. Triatoma rubrovaria (Blanchard, 1843) (Hemiptera, Reduviidae, Triatominae) II: Trophic resources and ecological observations of five populations collected in the state of Rio Grande do Sul, Brazil. Mem Inst Oswaldo Cruz 97: 1127-1131.

Almeida CE, Francischetti CN, Pacheco RS, Costa J 2003. Triatoma rubrovaria (Blanchard, 1843) (Hemiptera-Reduviidae-Triatominae) III: Patterns of feeding, defecation and resistance to starvation. Mem Inst Oswaldo Cruz 98: 367-371.

Almeida-Neto M, Guimaraẽs M, Guimaraẽs Jr PR, Loyola RD, Ulrich W 2008. A consistent metric for nestedness analysis in ecological systems: reconciling concept and quantification. Oikos 117: 1227-1239.

Andersen JF, Gudderra NP, Francischetti IMB, Ribeiro JMC 2005. The role of salivary lipocalins in blood feeding by Rhodnius prolixus. Arch Insect Biochem Physiol 58: 97-105.

Añez N, Nieves E, Cazorla D, Oviedo M, Lugo de Yarbuh A, Valera M 1994. Epidemiology of cutaneous leishmaniasis in Merida, Venezuela. III. Altitudinal distribution, age structure, natural infection and feeding behaviour of sandflies and their relation to the risk of transmission. Ann Trop Med Parasitol 88: 279-287.

Aragão MB 1983. Domiciliação de triatomíneos ou pré-adaptação à antropofilia e à ornitofilia? Rev Saude Publica 17: 51-55.

Araujo RN, Pereira MH, Soares AC, Pereira I, Diotaiuti L, Gontijo NF, Lehane MJ, Guarneri AA 2009. Effect of intestinal erythrocyte agglutination on the feeding performance of Triatoma brasiliensis (Hemiptera: Reduviidae). J Insect Physiol 55: 862-868.

Arévalo A, Carranza JC, Guhl F, Clavijo JA, Vallejo GA 2007. Comparación de los patrones de alimentación y defecación de Rhodnius colombiensis y Rhodnius prolixus (Hemiptera, Reduviidae, Triatominae) en condiciones de laboratorio. Biomedica 27 (Suppl. 1): 101-109.

Arzube Rodriguez M 1966. Investigación de la fuente alimenticia del Triatoma dimidiata Latr. 1811 (Hemiptera: Reduvidae), mediante la reacción de precipitina. Rev Ecuat Hig Med Trop 23: 137-152.

Azambuja P, Feder D, Garcia ES 1993. Effects of erythrocyte component diets on ecdysteroid production and ecdysis of Rhodnius prolixus larvae. J Insect Physiol 39: 13-16.

Barbosa SE, Diotaiuti L, Soares RPP, Pereira MH 1999. Differences in saliva composition among three Brazilian populations of Panstrongylus megistus (Hemiptera, 13 Reduviidae). Acta Tropica 72: 91-98.

Barretto MP 1967. Estudos sobre reservatórios e vectores silvestres do Trypanosoma cruzi. XXI: observações sobre a ecología do "Panstrongylus geniculatus" (Latreille, 1811) (Hemiptera, Reduviidae). Rev Bras Biol 27: 337-348.

Barretto MP 1968. Estudos sobre reservatórios e vectores silvestres do Trypanosoma cruzi. XXX: observações sobre a associação entre reservatórios e vectores, com especial referencia à região nordeste do estado de São Paulo. Rev Bras Biol 28: 481-494. 
Barretto MP 1971. Estudos sobre reservatórios e vectores silvestres do Trypanosoma cruzi. XLV: inquérito preliminar sobre triatomíneos silvestres no sul do estado de Mato Grosso, Brasil (Hemiptera, Reduviidae). Rev Bras Biol 31: 225-233.

Barretto MP, Albuquerque RDR, Funayama GK 1969. Estudos sobre reservatórios e vectores silvestres do Trypanosoma cruzi. XXXVI: investigações sobre triatomíneos de palmeiras no município de Uberaba, Minas Gerais, Brasil. Rev Bras Biol 29: 577-588.

Barretto MP, Carvalheiro JR 1966. Estudos sobre reservatórios e vectores silvestres do Trypanosoma cruzi. XII: inquérito preliminar sobre triatomíneos silvestres no município de Uberaba, Minas Gerais. Rev Bras Biol 26: 5-14.

Barretto MP, Ferraz de Siqueira A, Ferriolli Filho F, Carvalheiro JR 1966. Estudos sobre reservatórios e vectores silvestres do Trypanosoma cruzi. XI. Observações sobre tripanossomose americana no município de Ribeirão Preto, São Paulo. Rev Inst Med Trop Sao Paulo 8: 103-112.

Barrozo RB, Lazzari CR 2006. Orientation response of haematophagous bugs to $\mathrm{CO} 2$ : the effect of the temporal structure of the stimulus. J Comp Physiol A Neuroethol Sens Neural Behav Physiol 192: 827-831.

Bennet-Clark HC 1963a. Negative pressures produced in pharyngeal pump of blood-sucking bug, Rhodnius prolixus. J Exp Biol 40: $223-229$

Bennet-Clark HC 1963b. The control of meal size on blood sucking bug, Rhodnius prolixus. J Exp Biol 40: 741-750.

Bodin A, Vinauger C, Lazzari CR 2009a. Behavioural and physiological state dependency of host seeking in the blood-sucking insect Rhodnius prolixus. J Exp Biol 212: 2386-2393.

Bodin A, Vinauger C, Lazzari CR 2009b. State-dependency of hostseeking in Rhodnius prolixus: the post-ecdysis time. $J$ Insect Physiol 55: 574-579.

Bosseno MF, Barnabe C, Sierra MJR, Kengne P, Guerrero S, Lozano F, Ezequiel K, Gastélum M, Brenière SF 2009. Wild ecotopes and food habits of Triatoma longipennis infected by Trypanosoma cruzi lineages I and II in Mexico. Am J Trop Med Hyg 80: 988-991.

Bowman KO, Hutcheson K, Odum EP, Shenton LR 1971. Comments on the distribution of indices of diversity. In GP Patil, EC Pielou, WE Waters, Many species populations, ecosystems, and systems analysis. Statistical ecology 3, Penn State University Press, Harrisburg, p. 315-366.

Bradley TJ, Brethorst L, Robinson S, Hetz S 2003. Changes in the rate of $\mathrm{CO} 2$ release following feeding in the insect Rhodnius prolixus. Physiol Biochem Zool 76: 302-309.

Braga MV, Lima MM 1999. Feeding and defecation patterns of nymphs of Triatoma rubrofasciata (De Geer, 1773) (Hemiptera: Reduviidae) and its potential role as vector for Trypanosoma cruzi. Mem Inst Oswaldo Cruz 94: 127-129.

Braga MV, Lima MM 2001. Effects of food deprivation levels on the oogenesis of Panstrongylus megistus. Rev Saude Publica 35: 312-314.

Braga MV, Pinto ZT, Lima MM 1998. Life cycle and reproductive patterns of Triatoma rubrofasciata (De Geer, 1773) (Hemiptera: Reduviidae) under laboratory conditions. Mem Inst Oswaldo Cruz 93: 539-542.

Brandle M, Prinzing A, Pfeifer R, Brandl R 2002. Dietary niche breadth for Central European birds: correlations with speciesspecific traits. Evol Ecol Res 4: 643-657.

Breniere SF, Pietrokosky S, Gastelum EM, Bosseno MF, Soto MM, Ouaissi A, Kasten FL, Wisnivesky-Colli C 2004. Feeding patterns of Triatoma longipennis Usinger (Hemiptera, Reduviidae) in peridomestic habitats of a rural community in Jalisco State, Mexico. J Med Entomol 41: 1015-1020.
Briceño-León R 1990. La casa enferma. Sociología de la enfermedad de Chagas, Fondo Editorial Acta Científica Venezolana, Consorcio de Ediciones Capriles, Caracas, 153 pp.

Brumpt E 1927. Précis de parasitologie, Masson, Paris, 1100 pp.

Cabello DR 2001. Resistance to starvation of Rhodnius neivai Lent, 1953 (Hemiptera: Reduviidae: Triatominae) under experimental conditions. Mem Inst Oswaldo Cruz 96: 587-591.

Calegari L, Salvatella R, Guerrero J, Puime A, Rosa Y Basmadijan y R 1995. Habitos alimentarios de Triatoma rubrovaria (Blanchard, 1843) (Hemiptera, Triatominae), en diferentes situaciones eco-epidemiologicas. Bol Soc Zool Uruguay 9: 61-66.

Canale DM, Cecere MC, Chuit R, Gürtler RE 2000. Peridomestic distribution of Triatoma garciabesi and Triatoma guasayana in north-west Argentina. Med Vet Entomol 14: 383-390.

Canals M, Cruzat L, Molina MC, Ferreira A, Cattan PE 2001. Blood host sources of Mepraia spinolai (Heteroptera: Reduviidae), wild vector of Chagas disease in Chile. J Med Entomol 38: 303-307.

Canals M, Solis R, Tapia C, Ehrenfeld M, Cattan PE 1999. Comparison of some behavioral and physiological feeding parameters of Triatoma infestans Klug, 1834 and Mepraia spinolai Porter, 1934, vectors of Chagas disease in Chile. Mem Inst Oswaldo Cruz 94: 687-692.

Canavoso LE, Frede S, Rubiolo ER 2004. Metabolic pathways for dietary lipids in the midgut of hematophagous Panstrongylus megistus (Hemiptera: Reduviidae). Insect Biochem Mol Biol 34: 845-854.

Canavoso LE, Rubiolo ER 1998. Metabolic post-feeding changes in fat body and hemolymph of Dipetalogaster maximus (Hemiptera: Reduviidae). Mem Inst Oswaldo Cruz 93: 225-230.

Caranha L, Seixas LE, Rocha DS, Jurberg J, Galvão C 2006. Estudo das fontes alimentares de Panstrongylus lutzi (Neiva \& Pinto, 1923) (Hemiptera: Reduviidae: Triatominae) no estado do Ceará. Rev Soc Bras Med Trop 39: 347-351.

Carcavallo RU, Galíndez-Girón I, Jurberg J, Lent H 1999. Atlas of Chagas' disease vectors in the Americas, Fiocruz, Rio de Janeiro, $1217 \mathrm{pp}$.

Carneiro Freitas SP, Lorosa ES, Silva RDC, Carneiro FAL, Monte GTC 2005. Fontes alimentares de Triatoma pseudomaculata no Estado do Ceará, Brasil. Rev Saude Publica 39: 27-32.

Catalá de Montenegro S 1989. Relaciones entre consumo de sangre y ovogénesis en Triatoma infestans Klug, 1834 (Hemiptera-Reduviidae). Chagas 5: 3-10.

Ceballos LA, Vazquez-Prokopec GM, Cecere MC, Marcet PL, Gurtler RE 2005. Feeding rates, nutritional status and flight dispersal potential of peridomestic populations of Triatoma infestans in rural northwestern Argentina. Acta Trop 95: 149-159.

Chagas C 1909. Nova tripanosomiaze humana: estudos sobre a morfolojia e o ciclo evolutivo do Schizotrypanum cruzi, n. gen., n. sp., ajente etiolojico de nova entidade morbida do homem. Mem Inst Oswaldo Cruz 1: 159-218.

Chaves LF, Añez N 2004. Species co-occurrence and feeding behavior in sand fly transmission of American cutaneous leishmaniasis in western Venezuela. Acta Trop 92: 219-224.

Chaves LF, Harrington LC, Keogh CL, Nguyen AM, Kitron UD 2010. Blood feeding patterns of mosquitoes: random or structured? Front Zool 7: 3.

Christensen HA, Sousa OE, Vasquez AM 1988. Host feeding profiles of Triatoma dimidiata in peridomestic habitats of western Panama. Am J Trop Med Hyg 38: 477-479.

Christensen HA, Vasquez AM 1981. Host feeding profiles of Rhodnius pallescens (Hemiptera: Reduviidae) in rural villages of central Panama. Am J Trop Med Hyg 30: 278-283.

Christensen HA, Whitlaw JT, Chaniotis BN, Vásquez AM 1980. Sylvatic hosts of Rhodnius pallescens (Hemiptera: Reduviidae) nymphs in the Panama canal zone. J Med Entomol 17: 182. 
Cirano R, Zeledón R 1964. Observaciones sobre capacidad alimenticia y respiración de Triatoma infestans y Rhodnius prolixus. Rev Biol Trop 12: 271-285.

Colwell RK, Coddington JA 1994. Estimating terrestrial biodiversity through extrapolation. Philos Trans R Soc Lond B Biol Sci 345: 101-118.

Colwell RK, Hurtt GC 1994. Nonbiological gradients in species richness and a spurious rapoport effect. Am Nat 144: 570-595.

Correa RR, Aguiar AA 1952. O teste de precipitina na identificação da fonte alimentar do Triatoma infestans (Hemiptera, Reduviidae). Arq Hig Saude Publica 17: 3-8.

Cortéz MGR, Gonçalves TCM 1998. Resistance to starvation of Triatoma rubrofasciata (De Geer, 1773) under laboratory conditions (Hemiptera: Reduviidae: Triatominae). Mem Inst Oswaldo Cruz 93: 549-554.

Costa J, Marchon-Silva V 1998. Período de intermuda e resistência ao jejum de diferentes populações de Triatoma brasiliensis Neiva, 1911 (Hemiptera, Reduviidae, Triatominae). Entomol Vect 5: 23-34.

Costa J, Ribeiro de Almeida J, Britto C, Duarte R, Marchon-Silva V, Pacheco R da S 1998. Ecotopes, natural infection and trophic resources of Triatoma brasiliensis (Hemiptera: Reduviidae: Triatominae). Mem Inst Oswaldo Cruz 93: 7-13.

Costa JM, Jurberg J 1989. Estudos sobre a resistência ao jejum e aspectos nutricionais de Cavernicola lenti, Barrett \& Arias, 1985 (Hemiptera, Reduviidae, Triatominae). Mem Inst Oswaldo Cruz 84 (Suppl. IV): 129-137.

Costa JM, Jurberg J, Ribeiro de Almeida R 1987. Estudios bionômicos de Dipetalogaster maximus (Uhler, 1894) (Hemiptera-Triatominae). II. Influência da dieta sobre o ciclo biológico e resistência ao jejum. Mem Inst Oswaldo Cruz 81: 111-118.

Costa JM, Paranhos Perondini AL 1973. Resistência do Triatoma brasilensis ao jejum. Rev Saude Publica 7: 207-217.

Crocco LB, Catalá SS 1996. Feeding and defaecation patterns in Triatoma sordida. Mem Inst Oswaldo Cruz 91: 409-413.

Da Rocha e Silva EO, Ferraz A, Pacheco J 1979. Indices de dejeçâo das principais espécies de triatomineos presentes no estado de São Paulo, Brasil. In Congreso Internacional sobre Doenca de Chagas, Rio de Janeiro, 4 pp.

Davey K 2007. The interaction of feeding and mating in the hormonal control of egg production in Rhodnius prolixus. $J$ Insect Physiol 53: 208-215.

Davies C 1990. Interrupted feeding of blood-sucking insects: causes and effects. Parasitol Today 6: 19-22.

Dias E 1956. Observações sôbre eliminação de dejecoes e tempo de sucção em alguns triatomíneos sul-americanos. Mem Inst Oswaldo Cruz 54: 115-124.

Dias FBS, Bezerra CM, Machado EMM, Casanova C, Diotaiuti L 2008. Ecological aspects of Rhodnius nasutus Stål, 1859 (Hemiptera: Reduviidae: Triatominae) in palms of the Chapada do Araripe in Ceará, Brazil. Mem Inst Oswaldo Cruz 103: 824-830.

Dias JC 1965. Observações sobre o comportamento de triatomíneos brasileiros frente ao jejum, em laboratório. Rev Bras Malariol Doencas Trop 17: 55-63.

dos Santos Jr 2007. Avaliação da preferência alimentar de Panstrongylus megistus e infeccao por Trypanosoma cruzi, MSc Thesis, Pontifícia Universidade Católica do Rio Grande do Sul, Porto Alegre, Brasil, 55 pp.

Emmanuelle-Machado P, Koerich LB, Joukoski DDB, Carvalho-Pinto CJ, Grisard EC, Steindel M 2002. Biology of Triatoma klugi Carcavallo, Jurberg, Lent \& Galvão 2001 (Heteroptera: Reduviidae) under laboratory conditions: effects of distinct blood sources and susceptibility to Trypanosoma cruzi and Trypanosoma rangeli. Mem Inst Oswaldo Cruz 97: 583-587.
Faudry E, Lozzi SP, Santana JM, Sousa MV, Ricart CAO, Rocha PS, Macedo TC, Teixeira ARL 1999. Triatoma infestans saliva apyrases are $480 \mathrm{Kda}$ oligomers. XXVI Annual Meeting on Basic Research in Chagas Disease Vectors. Mem Inst Oswaldo Cruz 94 (Suppl. II): 249.

Feder D, Mello CB, Garcia ES, Azambuja P 1997. Immune responses in Rhodnius prolixus: influence of nutrition and ecdysone. J Insect Physiol 43: 513-519.

Forattini OP, Barata JMS, Ferreira Santos JL, Silveira AC 1981. Hábitos alimentares, infecção natural e distribuição de triotomíneos domiciliados na Região Nordeste do Brasil. Rev Saude Publica 15: 113-164.

Forattini OP, Barata JMS, Ferreira Santos JL, Silveira AC 1982. Hábitos alimentares, infecção natural e distribuição de triatomíneos domiciliados na Região Central do Brasil. Rev Saude Publica 16: 171-204.

Friend WG 1965. The gorging response in Rhodnius prolixus Stål. Can J Zool 43: 125-132.

Friend WG, Smith JJB 1971. Feeding in Rhodnius prolixus: mouthpart activity and salivation and their correlation with changes of electrical resistance. $J$ Insect Physiol 17: 233-243.

Friend WG, Smith JJB 1975. Feeding in Rhodnius prolixus: increasing sensitivity to ATP during prolonged food-deprivation. $J$ Insect Physiol 21: 1081-1084.

Friend WG, Smith JJB 1982. ATP analogs and other phosphate compounds as gorging stimulants for Rhodnius prolixus. $J$ Insect Physiol 28: 371-376.

Gajardo Tobar R 1952. Capacidad de ayuno de los triatominos chilenos. Bol Inf Parasit Chilenas 7: 56-59.

Galvão C, Jurberg J, Lent H 1996. Resistência ao jejum de Triatoma nitida Usinger, 1939 em laboratório (Hemiptera, Reduviidae, Triatominae). Mem Inst Oswaldo Cruz 91: 639-640.

Garcia ES, Guimarães JA 1979. Proteolytic enzymes in the Rhodnius prolixus midgut. Experientia 35: 305-306.

Gaunt M, Miles M 2000. The ecotopes and evolution of triatomine bugs (Triatominae) and their associated trypanosomes. Mem Inst Oswaldo Cruz 95: 557-565.

Gomes Dias-Lima A, Sherlock IA 2002. Resistência em jejum de diferentes espécies de triatomíneos (Hemiptera: Reduviidae: Triatominae). Entomol Vect 9: 47-70.

Gonçalves TCM, Rocha DS, Cunha RA 2000. Feeding patterns of Triatoma vitticeps in the state of Rio de Janeiro, Brazil. Rev Saude Publica 34: 348-352.

Gonçalves TCM, Victorio VMN, Jurberg J, Cunha V 1989. Biologia do Triatoma vitticeps (Stål, 1859) em condições de laboratório (Hemiptera: Reduviidae: Triatominae) - II. Resistência ao jejum. Mem Inst Oswaldo Cruz 84: 131-134.

Goodchild AJP 1955. Some observations on growth and egg production of the blood-sucking reduviids, Rhodnius prolixus and Triatoma infestans. Proc R Ent Soc Lond (A) 30: 137-144.

Gotelli NJ 2000. Null model analysis of species co-occurrence patterns. Ecology 81: 2606-2621.

Guerenstein PG, Lazzari CR 2009. Host-seeking: how triatomines acquire and make use of information to find blood. Acta Trop 110: $148-158$.

Guerrero de Moyeja L, Scorza JV 1981. Las fuentes alimenticias de algunos triatominae en los llanos centro-occidentales de Venezuela. Boletín Informativo de la Dirección de Malariología y Saneamiento Ambiental de Venezuela XXI: 129.

Gurtler RE, Ceballos LA, Ordonez-Krasnowski P, Lanati LA, Stariolo R, Kitron U 2009. Strong host-feeding preferences of the vector Triatoma infestans modified by vector density: implications for the epidemiology of Chagas disease. PLoS Negl Trop Dis 3: e447. 
Gurtler RE, Cohen JE, Cecere MC, Chuit R 1997. Shifting host choices of the vector of Chagas disease, Triatoma infestans, in relation to the availability of hosts in houses in north-west Argentina. $J$ Appl Ecol 34: 699-715.

Hamer GL, Kitron UD, Goldberg TL, Brawn JD, Loss SR, Ruiz MO, Hayes DB, Walker ED 2009. Host selection by Culex pipiens mosquitoes and West Nile virus amplification. Am J Trop Med Hyg 80: 268-278.

Hammer O, Harper DAT, Ryan PD 2001. PAST: Paleontological Statistics software package for education and data analysis. Palaeontol Electronica 4: 1-9.

Hays KL 1965. Longevity, fecundity and food intake of adult Triatoma sanguisuga (Leconte) (Hemiptera: Triatominae). J Med Entomol 2: 200-203.

Hutcheson K 1970. A test for comparing diversities based on the Shannon formula. $J$ Theor Biol 29: 151-154.

Hutchinson GE 1941. Ecological aspects of succession in natural populations. Am Nat 75: 406-418.

Hutchinson GE 1959. Homage to Santa-Rosalia or why are there so many kinds of animals. Am Nat 93: 145-159.

Jackson DA 1997. Compositional data in community ecology: the paradigm or peril of proportions? Ecology 78: 929-940.

Kaufman L, Rousseeuw PJ 1990. Finding groups in data: an introduction to cluster analysis, Wiley \& Sons, New York, 368 pp.

Klotz SA, Dorn PL, Klotz JH, Pinnas JL, Weirauch C, Kurtz JR, Schmidt J 2009. Feeding behavior of triatomines from the southwestern United States: an update on potential risk for transmission of Chagas disease. Acta Trop 111: 114-118.

Knierim F, Castro M, Villarroel F, Schenone H 1976. Estudio preliminar sobre la fuente de alimentación de Triatoma infestans y Triatoma spinolai mediante la reacción de doble difusión en gel. Bol Chil Parasitol 31: 33-35.

Kolasa J 1996. Nestedness and discontinuities in species-range-size distributions. Trends Ecol Evol 11: 433-433.

Kollien AH, Schaub GA 1998. The development of Trypanosoma cruzi (Trypanosomatidae) in the reduviid bug Triatoma infestans (Insecta): influence of starvation. J Eukaryot Microbiol 45: 59-63.

Lange AB, Orchard I, Barretto FM 1989. Changes in haemolymph serotonin levels associated with feeding in the blood-sucking bug, Rhodnius prolixus. J Insect Physiol 35: 393-399.

Lazzari CR, Lahondère C, Amino R, Insausti T 2009. Keeping cool: how blood-sucking insects avoid excessive warming during feeding, International Symposium on the Centennial of the Dicovery of Chagas Disease, Rio de Janeiro, July 8-10.

Lefevre T, Gouagna LC, Dabire KR, Elguero E, Fontenille D, Renaud F, Costantini C, Thomas F 2009. Beyond nature and nurture: phenotypic plasticity in blood-feeding behavior of Anopheles gambiae s.s. When humans are not readily accessible. Am J Trop Med Hyg 81: 1023-1029.

Lehane MJ 2005. Biology of blood-sucking insects, Harper Collins Academic, London, $288 \mathrm{pp}$.

Lehane MJ, McEwen PK, Whitaker CJ, Schofield CJ 1992. The role of temperature and nutritional status in flight initiation by Triatoma infestans. Acta Trop 52: 27-38.

Lehane MJ, Schofield CJ 1982. Flight initiation in Triatoma infestans (Klug) (Hemiptera, Reduviidae). Bull Entomol Res 72: 497-510.

Levins R 1968. Evolution in changing environments. Some theoretical explorations, Princeton University Press, Princeton, 120 pp.

Levins R, Awerbuch T, Brinkmann U, Eckardt I, Epstein P, Ford T, Makhoul N, Albuquerque de Possas C, Puccia C, Spielman A, Wilson ME 1994. The emergence of new diseases. Am Sci 82: 52-60.
Lima MM, Jurberg P, Almeida JR de 1986. Behavior of triatomines (Hemiptera: Reduviidae) vectors of Chagas disease. II. Influence of feeding, lighting and time of day on the number of matings, mating speed and duration of copulation of Panstrongylus megistus (Burm, 1835) under laboratory. Mem Inst Oswaldo Cruz 81: 381-388.

Lopez A, Crocco L, Morales G, Catalá 1999. Feeding frequency and nutritional status of peridomestic populations of Triatoma infestans from Argentina. Acta Trop 73: 275-281.

Lorosa ES, de Andrade RE, Menezes dos Santos S, Pereira CA, da Costa Vinhaes M, Jurberg J 1999. Estudo da infecção natural e fontes alimentares de Triatoma costalimai Verano and Galvão, 1959, Rhodnius neglectus Lent, 1954 e Psammolestes tertius Lent and Jurberg, 1965 do estado de Goiás, Brasil, através da técnica de precipitina. Entomol Vect 6: 405-414.

Lorosa ES, de Andrade RE, Serra MGA, Rebelo JMM, Vinhaes MC 1998. Estudo das fontes alimentares através da reação de precipitina e grau de infetividade em Triatoma rubrofasciata coletados na ilha de São Luis-Maranhão. Entomol Vect 5: 241-250.

Lorosa ES, Valente MVMP, Cunha V, Lent H, Jurberg J 2003. Source of Chagas disease in Arcadia, state of Rio de Janeiro, Brazil. Mem Inst Oswaldo Cruz 98: 885-887.

Maddrell SH 1963. Control of ingestion in Rhodnius prolixus Stål. Nature 198: 210-211.

Magurran AE 1988. Ecological diversity and its measurement, University Press, Princeton, 192 pp.

Maifrino LBM, Boainain E, Costa SCB, Sakae RS 1986. Influency in the duration and frequency at feeding in triatomines maintained in laboratory. Mem Inst Oswaldo Cruz 81 (Suppl. I): 161.

Malo EA, Ramirez-Rovelo A, Cruz-López L, Rojas JC 1993. Lifecycle and influence of age and feeding on the first mating of Triatoma mazoottii (Hemiptera, Reduviidae). Mem Inst Oswaldo Cruz 88: 203-206.

Martinez-Ibarra JA, Lopez MN, Robles MRH, Guillen YG 2003. Influence of the blood meal source on the biology of Meccus picturatus Usinger 1939 (Hemiptera: Reduviidae: Triatominae) under laboratory conditions. Mem Inst Oswaldo Cruz 98: 227-232.

Martinez-Ibarra JA, Novelo-López M 2004. Blood meals to molt, feeding time and postfeeding defecation delay of Meccus pallidipennis (Stål, 1872) (Hemiptera: Reduviidae) under laboratory conditions. Folia Entomol Mex 43: 313-319.

Mayer HF, Alcaraz IL 1955. Estudios relacionados con las fuentes alimentarias de Triatoma infestans (Hemiptera, Reduviidae). An Inst Med Reg Tucumán 4: 195-201.

Minter DM 1976. Feedings patterns of some triatomine vector species. In New approaches in American trypanosomiasis research, Pan American Health Organization, Washington, p. 33-47.

Montenegro SSC, Pasina L 1984. Consumo y utilización del alimento en adultos de Triatoma infestans Klug, 1834 (Hemiptera, Reduviidae). Physis 42: 127-133.

Moreira CJC, Spata MCD 2002. Dynamics of evolution and resistance to starvation of Triatoma vitticeps (Stål 1859) (Reduviidae: Triatominae) submitted to two different regimens of food deprivation. Mem Inst Oswaldo Cruz 97: 1049-1055.

Mota J, Chacon JC, Gutierrez-Cabrera AE, Sanchez-Cordero V, Wirtz RA, Ordoñez R, Panzera F, Ramsey JM 2007. Identification of blood meal source and infection with Trypanosoma cruzi of Chagas disease vectors using a multiplex cytochrome $\mathrm{b}$ polymerase chain reaction assay. Vector Borne Zoonotic Dis 7: 617-627.

Mulye H, Davey KG 1995. The feeding stimulus in Rhodnius prolixus is transmitted to the brain by a humoral factor. $J$ Exp Biol 198: 1087-1092.

Nattero J, Crocco LB, Rodriguez CS 2002. Feeding and defaecation behaviour of Triatoma patagonica (Del Ponte, 1929) (Hemiptera: Reduviidae). Mem Inst Oswaldo Cruz 97: 1063-1065. 
Nenadic O, Greenacre M 2007. Correspondence analysis in R, with two- and three-dimensional graphics: The ca package. J Stat Softw 20: 13.

Noireau F, Carbajal-De-La-Fuente AL, Lopes CM, Diotaiuti L 2005. Some considerations about the ecology of Triatominae. An Acad Bras Cienc 77: 431-436.

Noireau F, Dujardin JP 2001. Flight and nutritional status of sylvatic Triatoma sordida and Triatoma guasayana. Mem Inst Oswaldo Cruz 96: 385-389.

Otálora-Luna F, Perret JL, Guerin PM 2004. Appetence behaviours of the triatomine bug Rhodnius prolixus on a servosphere in response to the host metabolites carbon dioxide and ammonia. J Comp Physiol A Neuroethol Sens Neural Behav Physiol 190: 847-854.

Patterson JS, Gaunt MW 2010. Phylogenetic multi-locus codon models and molecular clocks reveal the monophyly of haematophagous reduviid bugs and their evolution at the formation of South America. Mol Phylogenet Evol 56: 608-621.

Patterson JW 1979. Effect of larval nutrition on egg-production in Rhodnius prolixus. J Insect Physiol 25: 311-314.

Paz D, Giménez H, Tomatis ME 1988. Hemolinfa de Triatoma infestans: cambios en volumen y proteínas totales después de una Ingesta. Chagas 5: 23-28.

Pedreira de Freitas JL, Siqueira AF, Alves Ferreira O 1960. Investigações epidemiológicas sobre triatomíneos de hábitos domésticos e silvestres com auxílio da reação de precipitina. Rev Inst Med Trop Sao Paulo 2: 90-99.

Peet RK 1974. The measurement of species diversity. Ann Rev Ecol System 5: 285-307.

Pellegrino J 1952. Observações sobre a resistencia do Triatoma infestans ao jejum. Rev Bras Biol 12: 317-320.

Pereira Barretto M 1968. Estudos sobre reservatórios e vectores silvestres do Trypanosoma cruzi. XXXI - Observações sobre a associação entre reservatórios e vectores, com especial referência à região nordeste do estado de São Paulo. Rev Bras Biol 28: 481-494.

Pereira Barretto M, Ferraz de Siqueira A, Ferriolli Filho F, Carvalheiro JR 1966. Estudos sobre reservatórios e vectores silvestres do Trypanosoma cruzi. XI. Observações sobre da tripanossomose americana no município de Ribeirão Preto, São Paulo. Rev Inst Med Trop Sao Paulo 8: 103-112.

Pereira H, Penido CM, Martins MS, Diotaiuti L 1998. Comparative kinetics of bloodmeal intake by Triatoma infestans and Rhodnius prolixus, the two principal vectors of Chagas disease. Med Vet Entomol 12: 84-88.

Petersen RM, Gurtler RE, Cecere MC, Rubel DN, Lauricella MA, Hansen D, Carlomagno MA 2001. Association between nutritional indicators and infectivity of dogs seroreactive for Trypanosoma cruzi in a rural area of northwestern Argentina. Parasitol Res 87: 208-214.

Pickett C, Friend WG 1965. The nutritionally essential amino acids of Rhodnius prolixus (Stål) determined with glucose-U-14C. J Insect Physiol 11: 1617-1623.

Piesman J, Sherlock IA, Christensen HA 1983. Host availability limits population-density of Panstrongylus megistus. Am J Trop Med Hyg 32: 1445-1450.

Pietrokovsky S, Bottazzi V, Schweigmann N, Haedo A, WisniveskyColli C 1996. Comparison of the blood meal size among Triatoma infestans, T. guasayana and T. sordida (Hemiptera: Reduviidae) of Argentina under laboratory conditions. Mem Inst Oswaldo Cruz 91: 241-242.

Pifano F 1973a. La dinámica epidemiológica de la enfermedad de Chagas en el Valle los Naranjos, Estado Carabobo, Venezuela. I. Contribución al estudio de los focos naturales silvestres del Schizotrypanum cruzi Chagas, 1909. Arch Venez Med Trop Parasitol Med 5: 3-29.
Pifano F 1973b. La dinámica epidemiológica de la enfermedad de Chagas en el Valle los Naranjos, Estado Carabobo, Venezuela. II. Infección chagásica en la población rural del area. Arch Venez Med Trop Parasitol Med 5: 31-45.

Pifano F 1973c. La enfermedad de chagas en Venezuela y sus problemas. Bol Acad Cienc Fís, Mat Nat (Venezuela) 33: 1-24.

Pineda V, Montalvo E, Alvarez D, Santamaría AM, Calzada JE, Saldaña A 2008. Feeding sources and trypanosome infection index of Rhodnius pallescens in a Chagas disease endemic area of Amador County, Panama. Rev Inst Med Trop Sao Paulo 50: 113-116.

Pinto J, Cáceres AG, Vega S, Martínez R, Náquira C 2008. Fuentes de alimentación de Panstrongylus herreri (Hemiptera: Triatominae) capturados en Utcubamba, Amazonas - Perú. Rev Peru Med Exp Salud Publica 25: 179-184.

Pires HHR, Borges EC, Andrade RE, Lorosa ES, Diotaiuti L 1999. Peridomiciliary infestation with Triatoma sordida Stål, 1859 in the County of Serra do Ramalho, Bahia, Brazil. Mem Inst Oswaldo Cruz 94: 147-149

Pizarro JC, Stevens L 2008. A new method for forensic DNA analysis of the blood meal in Chagas disease vectors demonstrated using Triatoma infestans from Chuquisaca, Bolivia. PloS ONE 3: E3585.

Pratt GE, Davey KG 1972. The corpus allatum and oogenesis in Rhodnius prolixus (Stål.) II. The effects of starvation. $J$ Exp Biol 56: 215-221.

Ponce C, Trochez H, Zeledón R 1974. Observaciones sobre enfermedad de Chagas y tripanosomiasis rangeli en tres ranchos del departamento Francisco Moran, Honduras. Rev Biol Trop 22: 289-303.

Quintal RE, Polanco GG 1977. Feeding preferences of Triatoma dimidiata maculipennis in Yucatan, Mexico. Am J Trop Med Hyg 26: $176-178$.

Rabinovich JE, Leal JA, Feliciangeli de Piñero D 1979. Domiciliary biting frequency and blood ingestion of the Chagas disease vector Rhodnius prolixus Stål (Hemiptera, Reduviidae), in Venezuela. Trans R Soc Trop Med Hyg 73: 272-283.

Regis L 1977. Nutrition et fecondité chez Triatoma infestans (Heteroptera: Reduviidae), PhD Thesis, Université Pierre et Marie Curie, Paris, 99 pp.

Rehder S, Zier U 2001. Letter to the editor: comment on "Logratio Analysis and Compositional Distance" by J Aitchison, C Barceló-Vidal, JA Martín-Fernández, V Pawlowsky-Glahn. Math Geol 33: 845-848.

Ribeiro JMC, Garcia ES 1980. The salivary and crop apyrase activity of Rhodnius prolixus. J Insect Physiol 26: 303-307.

Ribeiro JMC, Garcia ES 1981. The role of the salivary-glands in feeding in Rhodnius prolixus. $J$ Exp Biol 94: 219-230.

Rocha LLV, Neves CA, Zanuncio JC, Serrão JE 2010. Digestive cells in the midgut of Triatoma vitticeps (Stål, 1859) in different starvation periods. Comptes Rendus Biologies 333: 405-415.

Rodriguez CS, Carrizo SA, Crocco LB 2008. Comparison of feeding and defecation patterns between fifth-instar nymphs of Triatoma patagonica (Del Ponte, 1929) and Triatoma infestans (Klug, 1934) under laboratory conditions. Rev Soc Bras Med Trop 41: 330-333.

Rodriguez M 1966. Investigación de la fuente alimenticia del Triatoma dimidiata Latr. 1811 (Hemiptera: Reduviidae), Mediante la Reacción de Precipitina. Rev Ecuat Hig Med Trop 23: 137-152.

Rossell OJ 1976. Evaluación de la transmisión de la enfermedad de Chagas en dos caserios del estado Guárico, (Venezuela) sometidos a rociamientos, Universidad de los Andes, Facultad de Ciencias Mérida, Mírida, 76 pp.

Sandoval CM, Duarte R, Gutierrez R, Rocha DS, Angulo VM, Esteban L, Reyes M, Jurberg J, Galvão C 2004. Feeding sources and natural infection of Belminus herreri (Hemiptera, Reduviidae, 
Triatominae) from dwellings in Cesar, Colombia. Mem Inst Oswaldo Cruz 99: 137-140.

Sandoval CM, Joya MI, Gutiérrez R, Angulo VM 2000. Cleptohaematophagy of the triatomine bug Belminus herreri. Med Vet Entomol 14: 100-101.

Sandoval CM, Ortiz N, Jaimes D, Lorosa E, Galvão C, Rodriguez O, Scorza JV, Gutierrez R 2010. Feeding behaviour of Belminus ferroae (Hemiptera: Reduviidae), a predaceous Triatominae colonizing rural houses in Norte de Santander, Colombia. Med Vet Entomol 24: 124-131.

Sant'Anna MRV, Diotaiuti L, Gontijo AD, Gontijo ND, Pereira MH 2001. Feeding behaviour of morphologically similar Rhodnius species: influence of mechanical characteristics and salivary function. J Insect Physiol 47: 1459-1465.

Seixas Lorosa E, Bulhões Cahet DM, Esteves de Andrade R, Ferreira de Figueredo J, Jurberg J 2000a. O uso da técnica de precipitina no estudo do comportamento alimentar e grau de infectividade em Triatoma sordida (Stål, 1859), (Hemiptera - Reduviidae), coletados no estado do Mato Grosso, Brasil. Entomol Vect 7: 227-237.

Seixas Lorosa E, Esteves de Andrade R, Menezes dos Santos S, Pereira CA 1998. Estudio da infecção natural e da fonte alimentar do Triatoma sordida, (Stål, 1859), (Hemiptera - Reduviidae) na região norte de Minas Gerais, Brasil, através da reação de precipitina. Entomol Vect 5: 13-22.

Seixas Lorosa E, Esteves de Andrade R, Menezes dos Santos S, Pereira CA, Costa Vinhaes M 1999a. Estudio do comportamento alimentar de algumas espécies de triatomíneos com auxílio da técnica de precipitina. Entomol Vect 6: 112-124.

Seixas Lorosa E, Esteves de Andrade R, Pereira CA, Menezes dos Santos S, Jurberg J 1999b. Estudio das fontes alimentares do Triatoma sordida (Stål, 1859) do estado de Mato Grosso do Sul através da comparação das técnicas de precipitina e imunodifusão dupla. Entomol Vect 6: 156-165.

Seixas Lorosa E, Esteves de Andrade R, Pereira CA, Menezes dos Santos S, Jurberg J 1999c. Identificação das fontes alimentares de Triatoma sordida (Stål, 1859) (Hemiptera - Reduviidae) na região norte de Goiás, Brasil, através da técnica de precipitina. Entomol Vect 6: 294-305.

Seixas Lorosa E, Michelin Nunes I, Vinhaes M da C, Esteves de Andrade R, Jurberg J 2000b. Preferência alimentar de algumas espécies de triatomíneos capturados no estado do Rio Grande do Sul, Brasil, com auxílio da técnica de precipitina e grau de infectividade. Entomol Vect 7: 211-225.

Sherry TW 1984. Comparative dietary ecology of sympatric, insectivorous neotropical flycatchers (Tyrannidae). Ecol Monogr 54: 313-338.

Smith JJB, Friend WG 1972. Chemoreception in blood-feeding bug Rhodnius prolixus: possible role of cyclic AMP. J Insect Physiol 18: 2337-2342.

Smith JJB, Friend WG 1976. Potencies of combined doses of nucleotides as gorging stimulants for Rhodnius prolixus. J Insect Physiol 22: 1049-1052.

Soares AC, Carvalho-Tavares J, Gontijo ND, Dos Santos VC, Teixeira MM, Pereira MH 2006. Salivation pattern of Rhodnius prolixus (Reduviidae: Triatominae) in mouse skin. $J$ Insect Physiol 52: 468-472.

Steindel M, Toma HK, De Carvalho Pinto CJ, Grisard EC, Schlemper Jr BR 1994. Colonização de ecótopos artificiais pelo Panstrongylus megistus na Ilha De Santa Catarina, Florianópolis, Santa Catarina, Brasil. Rev Inst Med Trop Sao Paulo 36: 43-50.

Stone L, Roberts A 1990. The checkerboard score and species distributions. Oecologia 85: 74-79.
Taneja J, Guerin PM 1997. Ammonia attracts the haematophagous bug Triatoma infestans: behavioural and neurophysiological data on nymphs. J Comp Physiol A Neuroethol Sens Neural Behav Physiol 181: 21-34.

Teixeira ARL, Monteiro PS, Rebelo JM, Arganaraz ER, Vieira D, Lauria-Pires L, Nascimento R, Vexenat CA, Silva AR, Ault SK, Costa JM 2001. Emerging Chagas disease: trophic network and cycle of transmission of Trypanosoma cruzi from palm trees in the Amazon. Emerg Infect Dis 7: 100-112.

Tonn RJ, Otero MA, Mora E, Espinola H, Carcavallo RU 1978. Aspectos biológicos, ecológicos y distribución geográfica de Triatoma maculata (Erichson, 1848) (Hemiptera, Reduviidae) en Venezuela. Bol Dir Malariol Saneam Ambient 18: 16-24.

Ulrich W, Almeida M, Gotelli NJ 2009. A consumer's guide to nestedness analysis. Oikos 118: 3-17.

Ulrich W, Gotelli NJ 2007a. Disentangling community patterns of nestedness and species co-occurrence. Oikos 116: 2053-2061.

Ulrich W, Gotelli NJ 2007b. Null model analysis of species nestedness patterns. Ecology 88: 1824-1831.

Vallvé SL, Rojo H, Wisnivesky CC 1995. Ecología urbana de Triatoma infestans en Argentina. Asociación entre Triatoma infestans y palomares. Rev Saude Publica 29: 192-198.

Vamosi SM, Heard SB, Vamosi JC, Webb CO 2009. Emerging patterns in the comparative analysis of phylogenetic community structure. Mol Ecol 18: 572-592.

Venables WN, Ripley BD 2002. Modern Applied Statistics with SPlus, 4th ed., Springer-Verlag, New York, xi+495 pp.

Wigglesworth VB 1982. Fine structural changes in the fat body cells of Rhodnius (Hemiptera) during extreme starvation and recovery. J Cell Sci 53: 337-346.

Wisnivesky-Colli C, Gurtler RE, Solarz N, Salomon D, Ruiz A 1982. Feeding patterns of Triatoma infestans (Hemiptera, Reduviidae) in relation to transmission of American trypanosomiasis in Argentina. J Med Entomol 19: 645-654.

Wood SF 1951. Importance of feeding and defecation times of insect vectors in transmission of Chagas disease. J Econ Entomol 44: 52-54.

Wood SF 1976. Body-weight and blood meal size in Triatoma protracta (Hemiptera- Reduviidae). Ann Entomol Soc Am 69: 632-634.

Zabala NA, D’ Antonio M 1988. Patrones de alimentación y defecación en ninfas de $5^{\circ}$ estadio de cuatro especies de triatomineos (Rhodnius prolixus, Triatoma pallidipennis, T. infestans y T. brasiliensis, Hemiptera, Reduviidae). Acta Cient Venez 39: 79-83.

Zárate L, Zárate RJ, Tempelis CH, Goldsmith RS 1980. The biology and behavior of Triatoma barberi (Hemiptera: Reduviidae) in Mexico. I. Blood meal sources and infection with Trypanosoma cruzi. J Med Entomol 17: 103-116.

Zeledón R, Alvarado R, Jiron LF 1977. Observations on the feeding and defecation patterns of three triatomine species (Hemiptera: Reduviidae). Acta Trop 34: 65-77.

Zeledón R, Calvo N, Montenegro VM, Lorosa ES, Arévalo C 2005. A survey on Triatoma dimidiata in an urban area of the province of Heredia, Costa Rica. Mem Inst Oswaldo Cruz 100: 607-612.

Zeledón R, Guardia V, Zúñiga A, Swartzwelder JC 1970. Biology and ethology of Triatoma dimidiata (Latreille, 1811). I. Life cycle, amount of blood ingested, resistance to starvation and size of adults. J Med Entomol 7: 313-319.

Zingales B, Andrade SG, Briones MRS, Campbell DA, Chiari E, Fernandes $\mathrm{O}$, Guhl F, Lages-Silva E, Macedo AM, Machado CR, Miles MA, Romanha AJ, Sturm NR, Tibayrenc M, Schijman AG 2009. A new consensus for Trypanosoma cruzi intraspecific nomenclature: second revision meeting recommends TcI to TcVI. Mem Inst Oswaldo Cruz 104: 1051-1054. 
TABLE
number of bloods-source by yeach of the 19 axonomic categories seced in this compilation and the bibliographic source

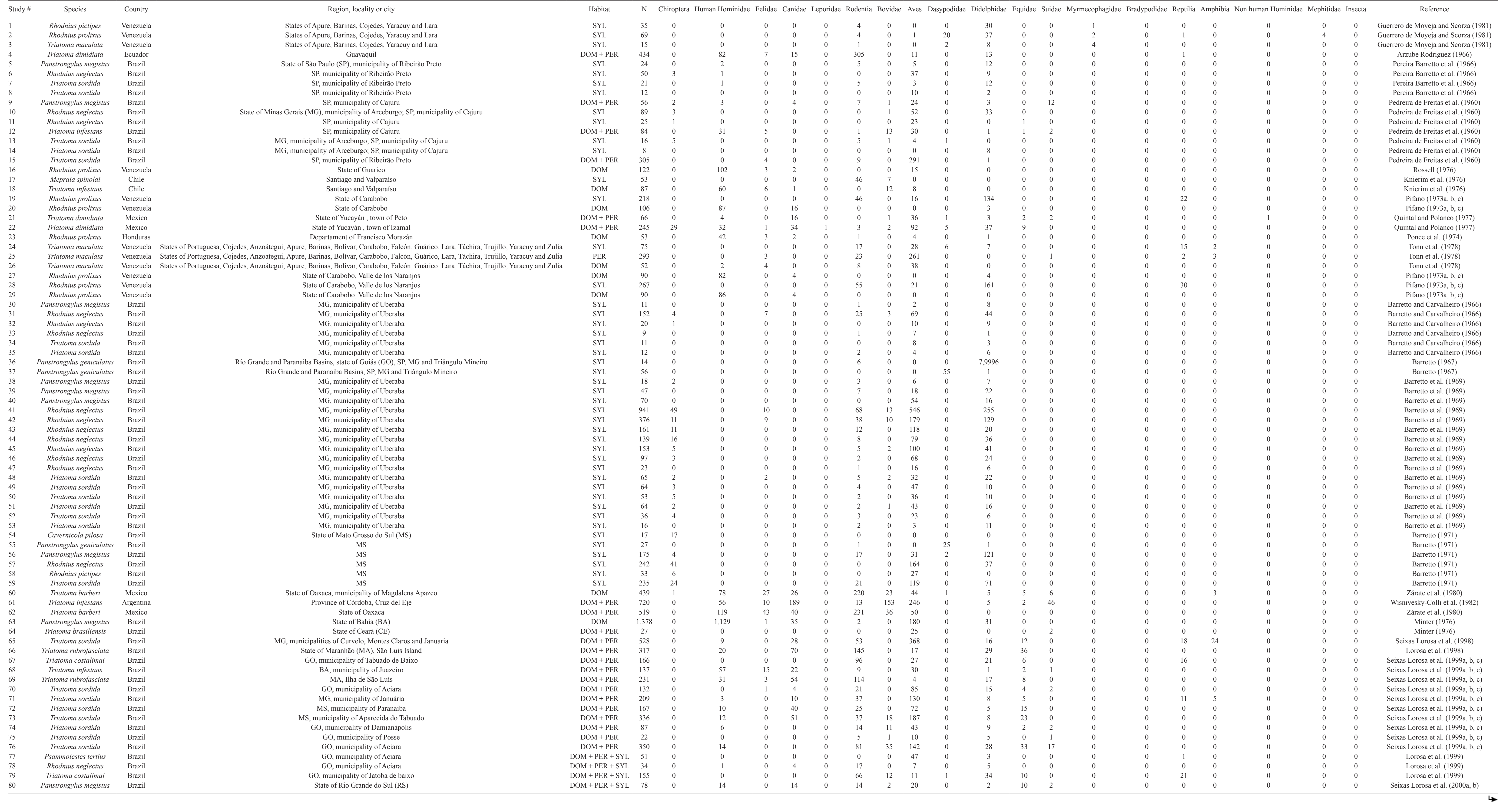



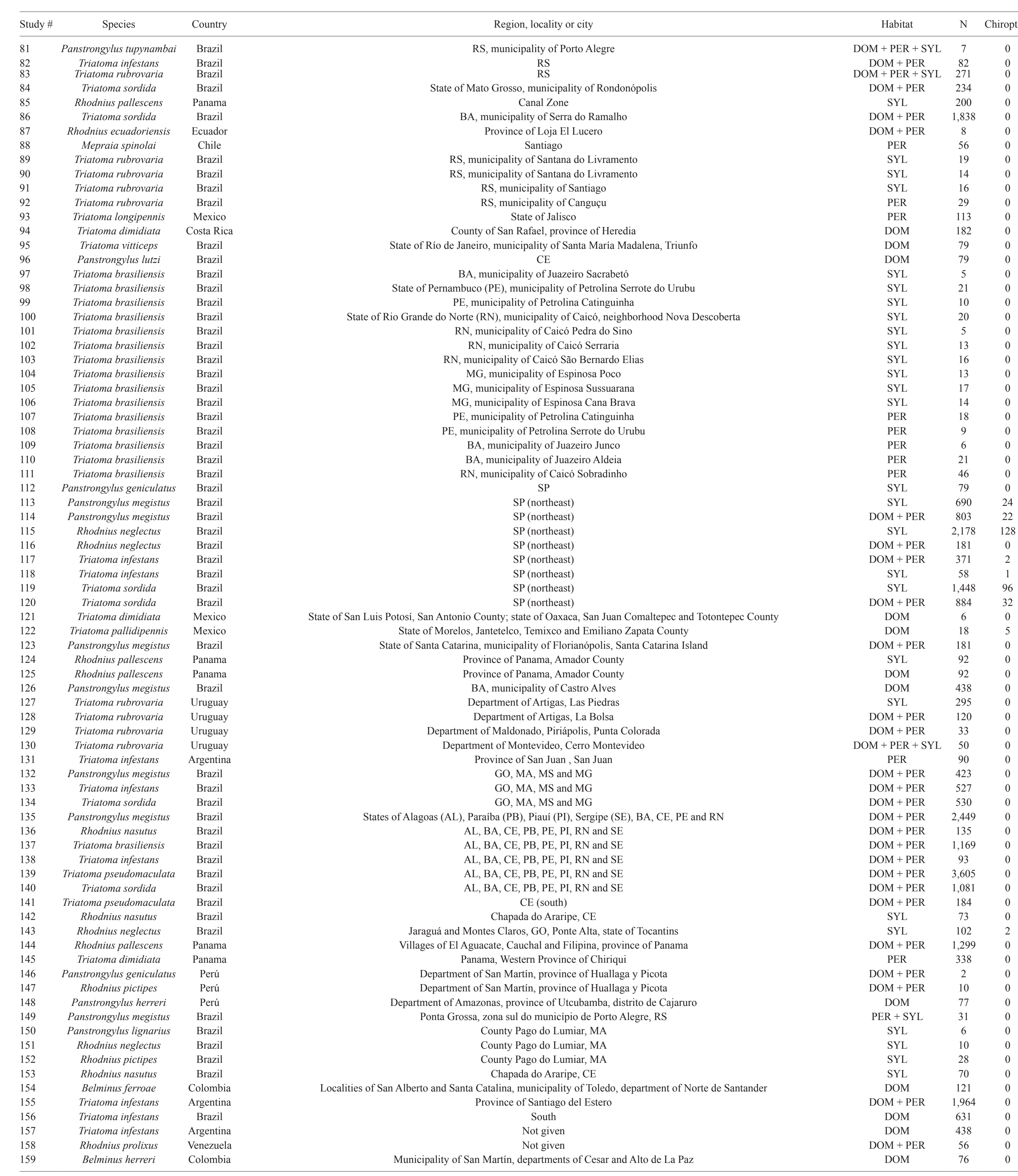

Lorosa e tal. (2000a, b)
(2)

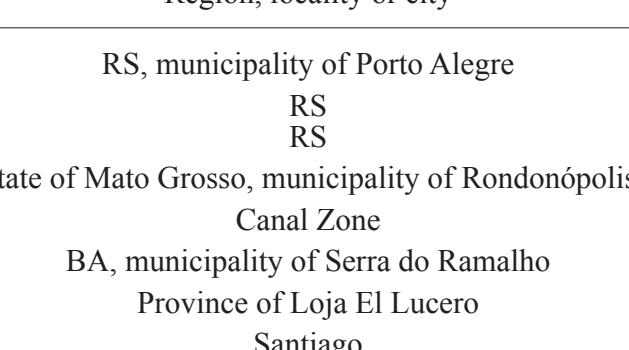

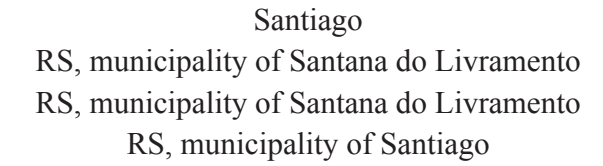

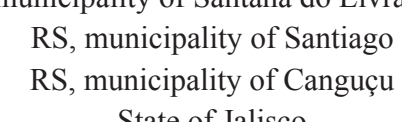

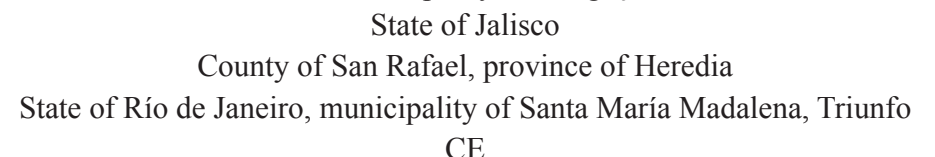

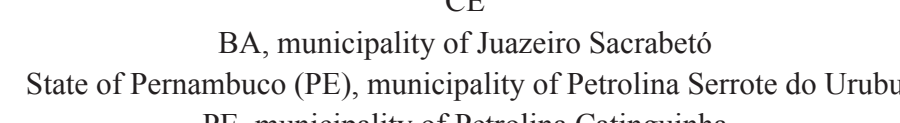

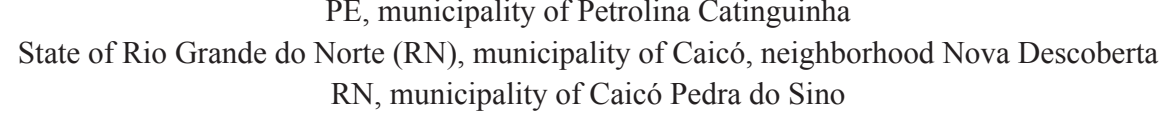

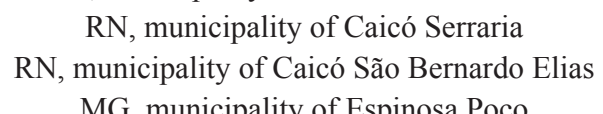

MG, muncipipality of Espininsa Aussuarana
MG, municipality of Espinsos Cana Brava

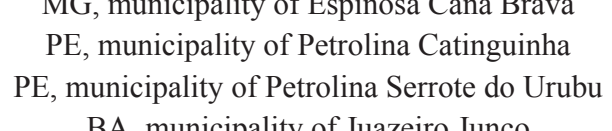

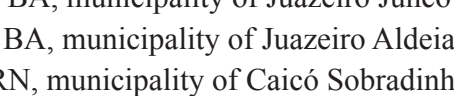

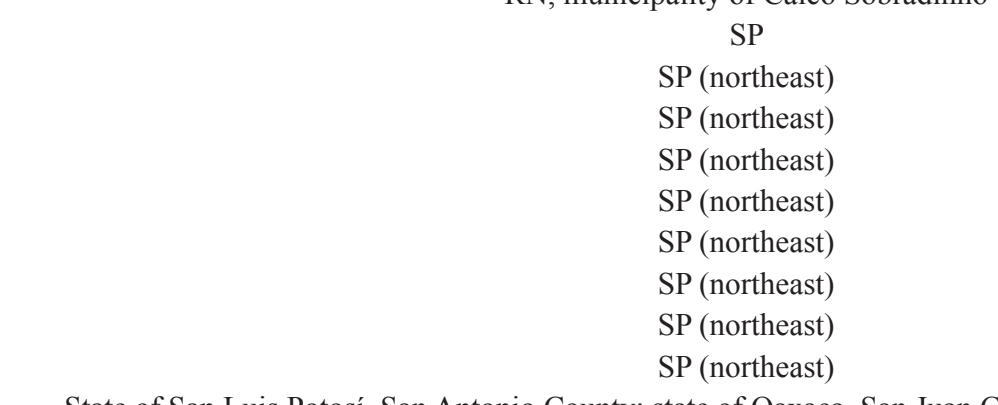

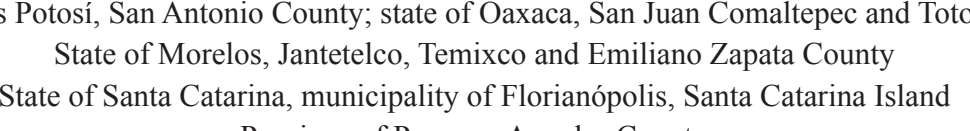

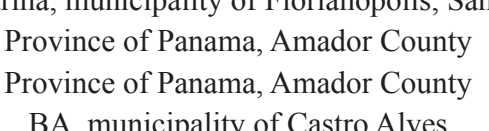

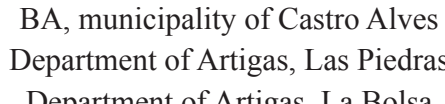

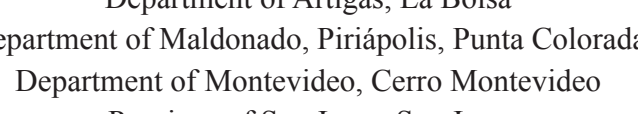

Province of San Juan, San Juan
Co, MA, MS and MG

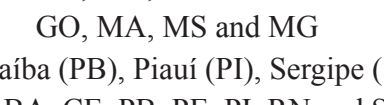

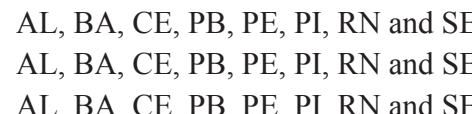

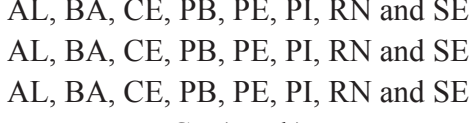

CE (south)
Chapada do Araripe, CE
sc Claros, , Gi, Ponte Alta, state of Tocantins

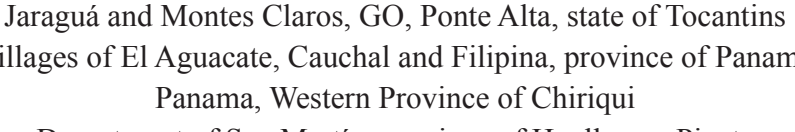

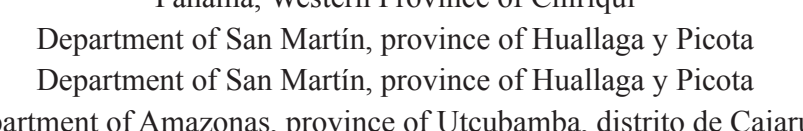

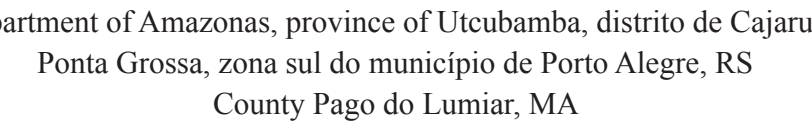

County pago do Lumiar, MA
County Paggo do Lumiar, MA

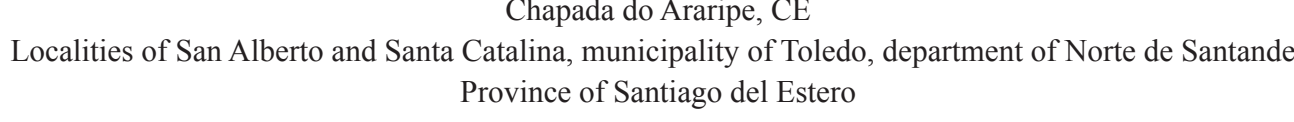

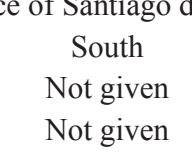

Municipality of San Martin, Nepartments of Cesar and Alto de L L Para
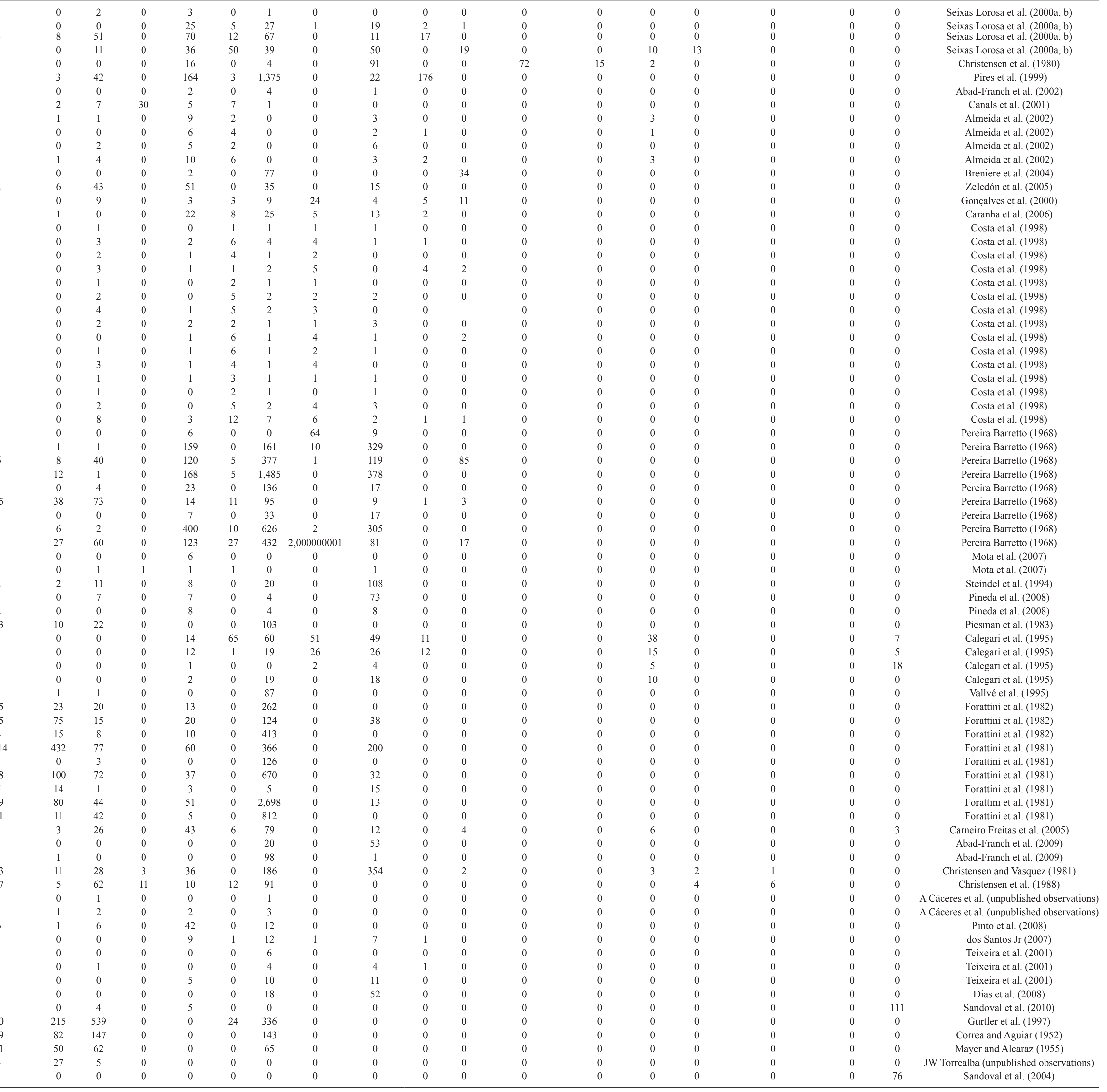